\title{
Variability in fluvial geomorphic response to anthropogenic disturbance
}

\author{
Gert Verstraeten*, Nils Broothaerts, Maarten Van Loo, Bastiaan Notebaert, Koen D'Haen, \\ Bert Dusar, Hanne De Brue
}

Division of Geography and Tourism, Department Earth and Environmental Sciences, KU Leuven, Celestijnenlaan 200E, B-3001 Leuven, Belgium Center for Archaeological Sciences, KU Leuven, Belgium

\section{A R T I C L E I N F O}

Article history:

Received 1 December 2016

Received in revised form 21 March 2017

Accepted 22 March 2017

Available online $\mathrm{xxxx}$

\section{Keywords:}

Sediment budget

Floodplain aggradation

Legacy sediment

Geomorphic response

Human impact

\begin{abstract}
A B S T R A C T
Humans have greatly impacted the processes and intensities of erosion, sediment transport and storage since the introduction of agriculture. In many regions around the world, accelerated floodplain sedimentation can be related to increases in human pressure on the environment. However, the relation between the intensity of anthropogenic disturbance and the magnitude of change in fluvial sediment dynamics is not straightforward and often non-linear. Here, we review a number of case studies from contrasting environmental settings in the European loess belt, the Eastern Mediterranean mountain ranges and the eastern USA. Detailed field-based sediment archive studies and sediment budgets covering time periods ranging from 200 to over 5000 year, as well as the use of pollen and sediment provenance techniques, show that no overarching concept of changes in floodplain sedimentation following anthropogenic disturbance can be established. Slope-channel (dis)connectivity controls the existence of thresholds or tipping points that need to be crossed before significant changes in downstream sediment dynamics are recorded following human impact. This coupling can be related to characteristics of human pressure such as its duration, intensity and spatial patterns, but also to the geomorphic and tectonic setting. Furthermore, internal feedback mechanisms, such as those between erosion and soil thickness, further complicate the story. All these factors controlling the propagation of sediment from eroding hillslopes to river channels vary between regions. Hence, only unique patterns of fluvial geomorphic response can be identified. As a result, unravelling the human impact from current-day sediment archives and predicting the impact of future human disturbances on fluvial sediment dynamics remain a major challenge. This has important implications for interpreting contemporary sediment yields as well as downstream sediment records in large floodplains, deltas and the marine environment, in terms of changes in the drivers of environmental change.

(c) 2017 Elsevier B.V. All rights reserved.
\end{abstract}

\section{Introduction}

The production, transportation and deposition of sediments are natural geomorphic processes controlled by external drivers such as climate, vegetation cover, as well as tectonics. When these processes are in steady-state, a fluvial landscape in dynamic equilibrium will develop. Significant changes in one or more of the controlling factors will shift the system away from equilibrium, and hence, the fluvial landscape may experience important morphological changes (Schumm, 1977; Blum and Törnqvist, 2000). Climatic transitions (e.g., from cold to warm or dry to wet) are typically considered to be responsible for rivers to incise and aggrade, whilst periods of climatic stability typically correspond to stable river systems (e.g. Knox, 1972; Vandenberghe, 1995; Vandenberghe, 2008). Climate not only has a direct impact through the amount and erosivity of rainfall, it also controls vegetation cover and hence the susceptibility of the land for erosive rain events.

\footnotetext{
* Corresponding author.

E-mail address: gert.verstraeten@kuleuven.be (G. Verstraeten).
}

However, during the last few thousand years, human pressure has become the major factor controlling changes in vegetation cover (Ellis et al., 2013). Clearing land for timber or for agricultural purposes results, especially in temperate and tropical environments, in a reduced vegetation cover that is not in equilibrium with local climate. Hence, erosion rates under cropland are on average 10 to 100 times higher compared to long-term geologic baseline values, whereas for individual sites accelerated erosion rates on cropland can be $>1000$-fold higher compared to slopes under native vegetation (Montgomery, 2007b). Such dramatic increases in sediment production also change the delivery of sediment to the fluvial system shifting it away from the mid-Holocene dynamic equilibrium state (Meybeck and Vörösmarty, 2005). Many rivers around the world have responded to this increase in sediment delivery through aggradation to an extent that the anthropogenic signal in river systems can be identified as a unique sedimentary stratigraphic unit or 'legacy sediment' (James, 2013). Although establishing a relation between intensities of anthropogenic pressure, soil erosion, floodplain sedimentation and fluvial sediment delivery is tempting, not only for understanding how humans have changed the Earth's surface but also 
to better implement control measures, this is far from straightforward. Several studies have shown that the buffering capacity of fluvial systems increases with spatial scale, thus decreasing the human impact signal with increasing catchment area (e.g. Dearing and Jones, 2003; Vanmaercke et al., 2015). It is therefore not surprising that, at the global scale, sediment delivery towards the ocean has not changed significantly over the last few hundred years despite the growing human impact due to land-cover changes and dam construction (Syvitski et al., 2005). The buffering capacity of slopes and floodplains, however, may vary from catchment to catchment, thus resulting in highly variable sediment delivery ratios (SDR). Changes in anthropogenic land cover may reduce the input of fresh sediment into the fluvial system, however, levels of sediment yield may retain higher levels as older legacy sediment is being reworked. Rivers may therefore remain in disequilibrium for a longer time period, even when the original disturbance factor has disappeared (e.g. Trimble, 1975). Similar observations have been made for formerly glaciated catchments where sediment yields are not in equilibrium with contemporary erosion rates (Church and Slaymaker, 1989). Such notions of the complex response of the fluvial system to disturbance (see also Schumm, 1977) raise questions about the use of a simple SDR and the need to unlock the black box of the sediment delivery problem (Trimble, 1975; Walling, 1983; de Vente et al., 2007; Burt and Allison, 2010).

Several models have been proposed that aim to explain the evolution of the geomorphic response to human impact in space and time, and that go beyond the SDR model. A traditional representation is the sediment cascade model whereby eroded sediment is cascading downslope from sink to sink (Lang and Hönscheidt, 1999; Zolitschka et al., 2003). Such a cascade model can be further conceptualised using the reservoir theory whereby the various sediment storage compartments are considered as reservoirs that generate outflow to the lower reservoir (Hoffmann, 2015). Within the cascade model, it is often assumed that all voids in the landscape need to be filled first before transfer to the next downstream sink can take place. In areas with a long history of human-induced soil erosion on agricultural land this implies that colluvial sinks respond first to human impact and only in a later stage floodplains will respond. Other conceptual models focus on the (dis)connectivity between various sources and sinks of sediment and how the coupling between slopes and channels may change through time (e.g. Fryirs, 2013). Slope-channel coupling is often considered in conjunction with the sediment cascade model: sediment cascades from one sink to another sink when the connectivity between both sinks is established (Lang et al., 2003a; Hoffmann, 2015). Whilst these models mainly focus on the spatial propagation of sediment generated by human impact, the 'fast in, slow out' principle first proposed by Trimble (2010), focuses more on the timescales at which the geomorphic response to disturbance events operate. Trimble (2010) suggests that sediment pulses may generate severe aggradation in fluvial systems in only a few decades to centuries following the disturbance event, whilst it may take millennia to remove the sediment again once the disturbance has been erased. This concept is linked to the residence time of sediment in general, and of legacy sediment in particular. Hoffmann (2015) used the reservoir theory discussed above to calculate cumulative SDR-values and the mean sediment residence time of

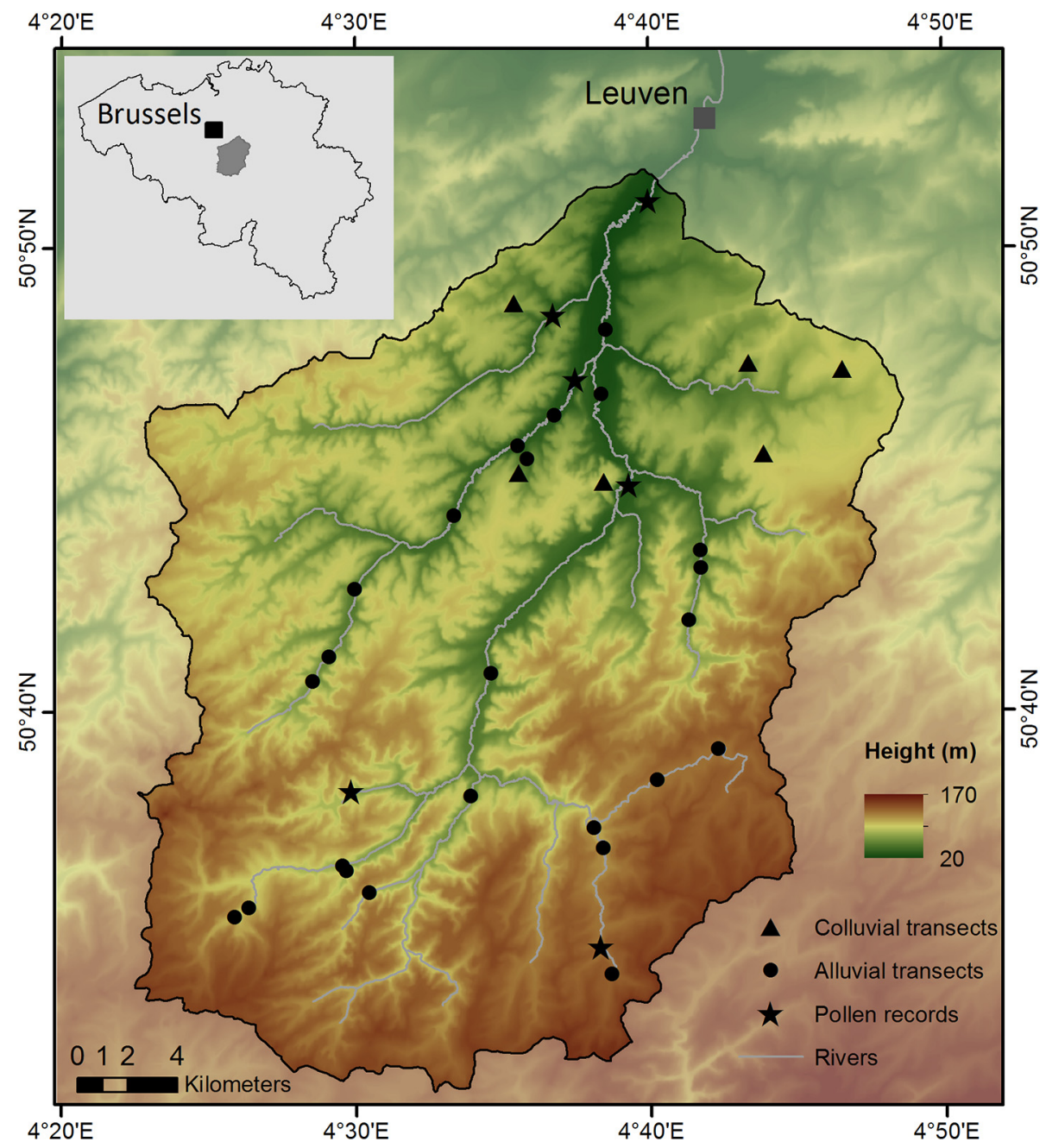

Fig. 1. Overview of the Dijle catchment 
anthropogenic alluvium for the Aufsess catchment in central Germany, whilst Phillips et al. (2007) estimated the alluvial residence time from the average age of alluvial deposits for the Waipoa catchment in New Zealand. However, several assumptions have to be made and the residence time computation will depend strongly on the preservation potential of the sediment, and thus on the relative importance of lateral reworking (Lewin and Macklin, 2003). Several reviews of historic erosion and sedimentation studies (e.g. Dotterweich, 2008; Notebaert and Verstraeten, 2010; Dusar et al., 2011; Bellin et al., 2013) furthermore show that the timing, rate and spatial extent of the anthropogenic impact on fluvial sedimentation is highly variable. A detailed understanding of the mechanisms controlling the propagation of anthropogenic signals in river systems is needed to better appreciate and quantify the fate and residence time of anthropogenic legacy sediment.

This paper discusses the variability in long-term geomorphic response of the fluvial system to human impact. It will provide an indepth review of three case studies from different environments, and will re-analyse these data in order to gain fundamental insights into the various processes and factors controlling the human impact on sediment dynamics. When discussing the specific history of the geomorphic response for each of the three case studies, we will see to what extent the sediment cascade model, the connectivity model and the 'fast-in, slow-out' model are valid, and how these models can be related. The first study site, the Dijle catchment in the central Belgian loess belt, is representative of a temperate environment with thick fertile soil and a long tradition of human impact through agriculture. Second, the Sagalassos region in southwestern Turkey represents a typical Mediterranean mountain environment with restricted soil depth, also with a millennia-long tradition of human impact, in particular for the classical period. Finally, the New World (USA, Australia) only experienced major human disturbance during the last two to three centuries. Here data are used on accelerated sedimentation for a few US catchments. When discussing the variability in geomorphic response, we will refer to several other studies on fluvial sediment dynamics worldwide to support the conclusions drawn from the analysis of the three case studies. However, we do not envisage a thorough review of the many studies dealing with human impact on fluvial systems throughout history as this is beyond the scope of this paper. Rather, we will propose several new conceptual models of geomorphic response to human impact under various conditions that can be further extended and validated when compared to other case studies.

\section{Presentation of case studies}

\subsection{Dijle catchment, Belgium}

The Dijle catchment $\left(758 \mathrm{~km}^{2}\right)$ is situated in central Belgium and is part of the western and central European Loess Belt (Fig. 1). The catchment is characterized by an undulating plateau landscape with heights varying between $168 \mathrm{~m}$ a.s.l. in the south and $75 \mathrm{~m}$ a.s.l. in the north. The River Dijle and its tributaries have incised into the plateau and are flowing in broad floodplains situated $40-60 \mathrm{~m}$ below the plateau. Floodplain width varies from a few tens of meters in the headwater catchments to nearly $2 \mathrm{~km}$ in the downstream reaches. Slope gradients on the plateau are generally lower than $5 \%$, however, steeper slope gradients up to $50 \%$ can be found along the main valley slopes. Soils are dominated by Luvisols (Alfisols in USA system) developed in latePleistocene loess deposits. Loess thickness generally varies between two and several meters. Locally, however, the loess cover is (nearly) absent and here Palaeogene marine sand deposits outcrop.

At present, $37 \%$ of the catchment is under cropland, mainly on the plateau, whereas $18 \%$ is covered by grassland, mainly as pasture in the floodplain. Forests (13\%) are situated on the steeper valley slopes, in the floodplain itself, as well as on the sandy outcrops on the plateau. Large parts of the catchment are now urbanised (30\%). However, up to the 19th century, cropland dominated the landscape for centuries.
Based on six well-dated pollen records recovered from the floodplain, the average proportion of cropland, forest and grassland could be estimated through the application of a regional pollen dispersion model (Broothaerts et al., 2014c; De Brue, 2016). Pollen data show that the catchment was covered by a dense forest until the onset of the Neolithic (Broothaerts et al., 2014c). Although the Linearbandkeramik culture arrived in the Belgian loess belt around $5200 \mathrm{BC}$ (Vanmontfort, 2007), the oldest known Neolithic site in the catchment dates from ca 4200 BC (Crombé et al., 2007; Vanmontfort, 2007). During the Neolithic Period anthropogenic impact nevertheless remained limited to local deforestations not exceeding 20\%. From the beginning of the Bronze Age (ca. $1900 \mathrm{BC}$ ), more intense anthropogenic impact is reflected in the pollen records (forest cover estimated at $\mathrm{ca}$. 70\%), with peaks during the Roman Period (1 AD-200 AD; forest cover estimated at ca. 35\%) and especially from the Medieval Period onwards (post $1000 \mathrm{AD}$; forest cover $<20 \%$ ) (Broothaerts et al., 2014c). The long history of human impact in a hilly landscape dominated by loess soils mobilised large amounts of soil through surface-water erosion processes. Over the last decade, the Dijle catchment and its tributaries have been the focus of numerous studies on long-term erosion and sediment fluxes (Rommens et al., 2005; Rommens et al., 2006; Rommens et al., 2007; Notebaert et al., 2009; Verstraeten et al., 2009; Notebaert et al., 2011a; Notebaert et al., 2011b; Notebaert et al., 2011c). Historic rates of soil erosion and sediment deposition on slopes (colluvium) and in floodplains (alluvium) have been estimated through intensive soil coring and sediment budgeting. Intense soil erosion on the slopes resulted in soil profile truncation that can be quantified by comparing contemporary soil profiles with reference soil profiles on flat plateau morphologies (Rommens et al., 2005; Notebaert et al., 2009; Vanwalleghem et al., 2010). Average net erosion rates obtained for 800 soil corings at six locations vary between $\pm 0.5 \mathrm{~m}$ on gentle slopes to on average $1.6 \mathrm{~m}$ on slopes steeper than $8 \%$. Extrapolation of these average values to the entire Dijle catchment allowed an erosion and colluvial sediment budget to be constructed for the Holocene period (Fig. 2; Notebaert et al., 2009). Alluvial
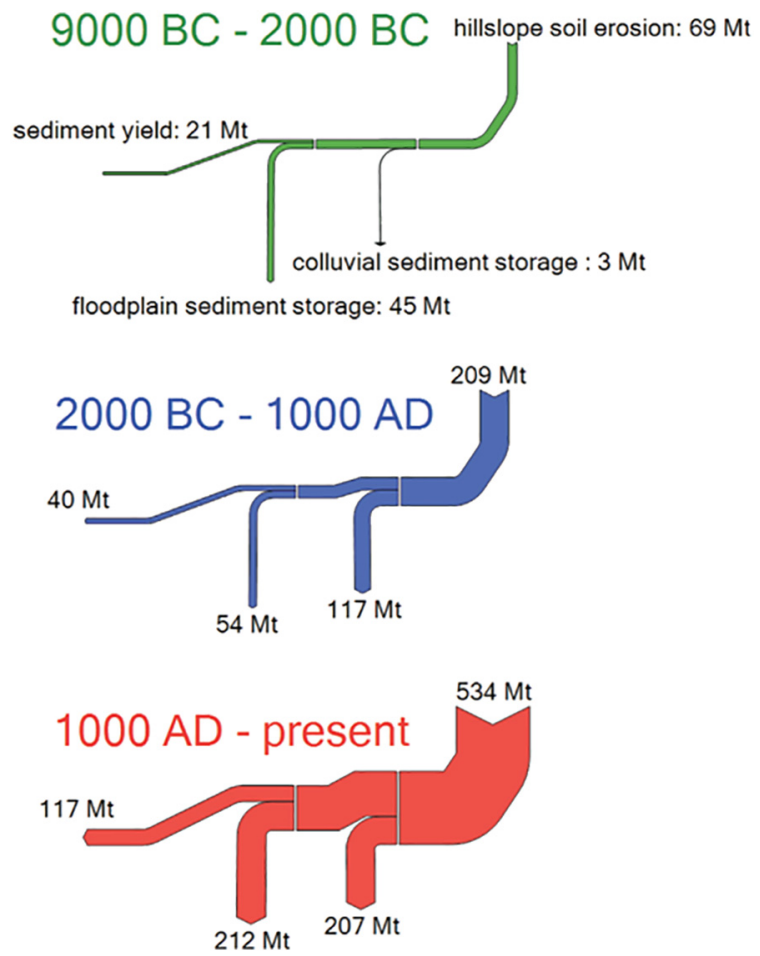

Fig. 2. Time-differentiated sediment budget for the Dijle catchment (updated from Notebaert et al., 2009; Verstraeten, 2012). Note that all values are displayed in absolute amounts (Mt = megaton) and that the length of each period is significantly different. Reprinted from Verstraeten (2012). 


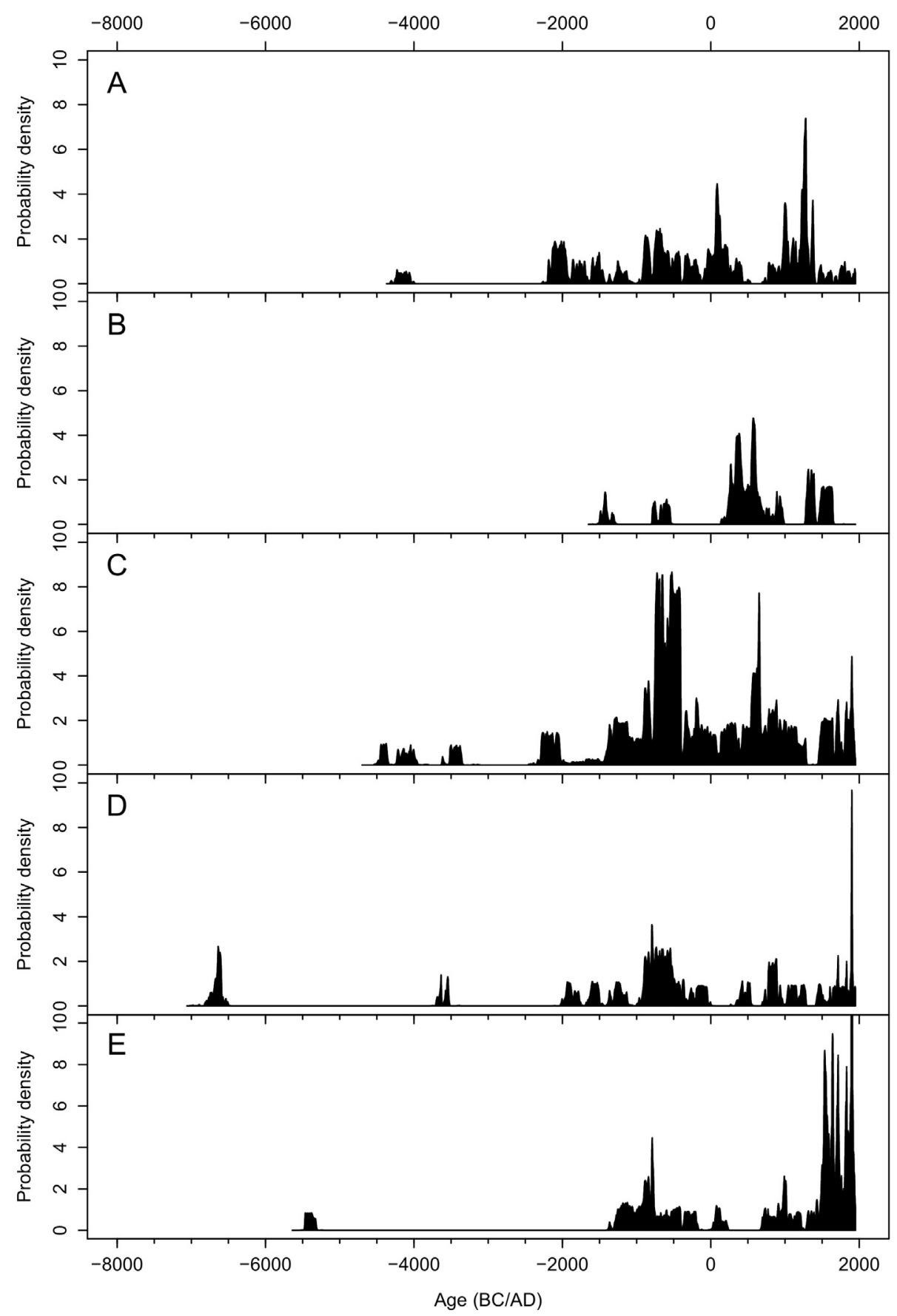

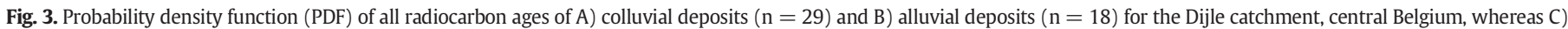

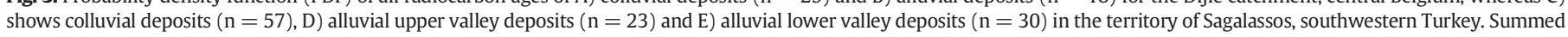

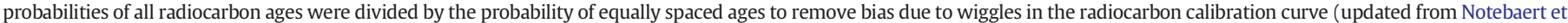
al., 2011b; Dusar et al., 2012; Broothaerts et al., 2014a; Broothaerts et al., 2014c).

sediment storage has been estimated through 350 soil corings distributed across 25 floodplain cross sections. Floodplain architecture shows first of all the development of a 1- to 3-m thick peat layer on top of braided sandy channel deposits. The peat corresponds to a wetland environment without a clear drainage channel in which organic matter could accumulate. The peat is covered by $2-8 \mathrm{~m}$ of silt-loam levee and in particular backswamp alluvial deposits that were deposited by suspended sediment from soil eroded off the hillslopes. The transition from a wetland environment to an alluvial floodplain began with the development of a meandering river channel with cohesive fine-grained banks. The alluvial sediment budget only incorporates the mineral sediment mass, not the organic matter. Net sediment exported over the
Holocene was estimated as the residual sediment budget term (i.e., erosion minus colluvial sediment storage minus alluvial sediment storage).

The chronology of sediment storage was established through 165 AMS radiocarbon ages and 11 OSL burial ages of floodplain deposits and 21 AMS radiocarbon ages of colluvial deposits (Notebaert et al., 2011b; Broothaerts et al., 2014a). Fig. 3 shows the probability density function (PDF) for colluvial and alluvial mineral sediment deposits. PDFs are made by the addition of the probability functions of individual calibrated radiocarbon ages, and are frequently used to identify periods with increased sediment dynamics (Thorndycraft and Benito, 2006b; Thorndycraft and Benito, 2006a; Hoffmann et al., 2009; Macklin et al., 2010). Although the use of such PDFs to analyse short-duration events 


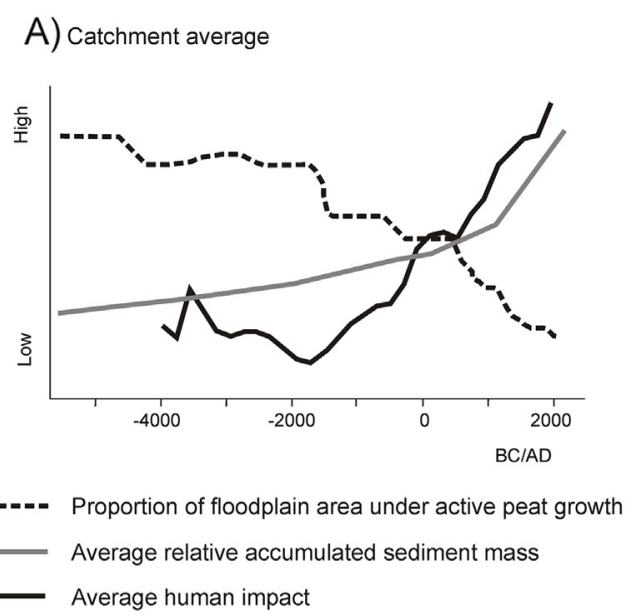

B) Narrow floodplain

C) Wide floodplain
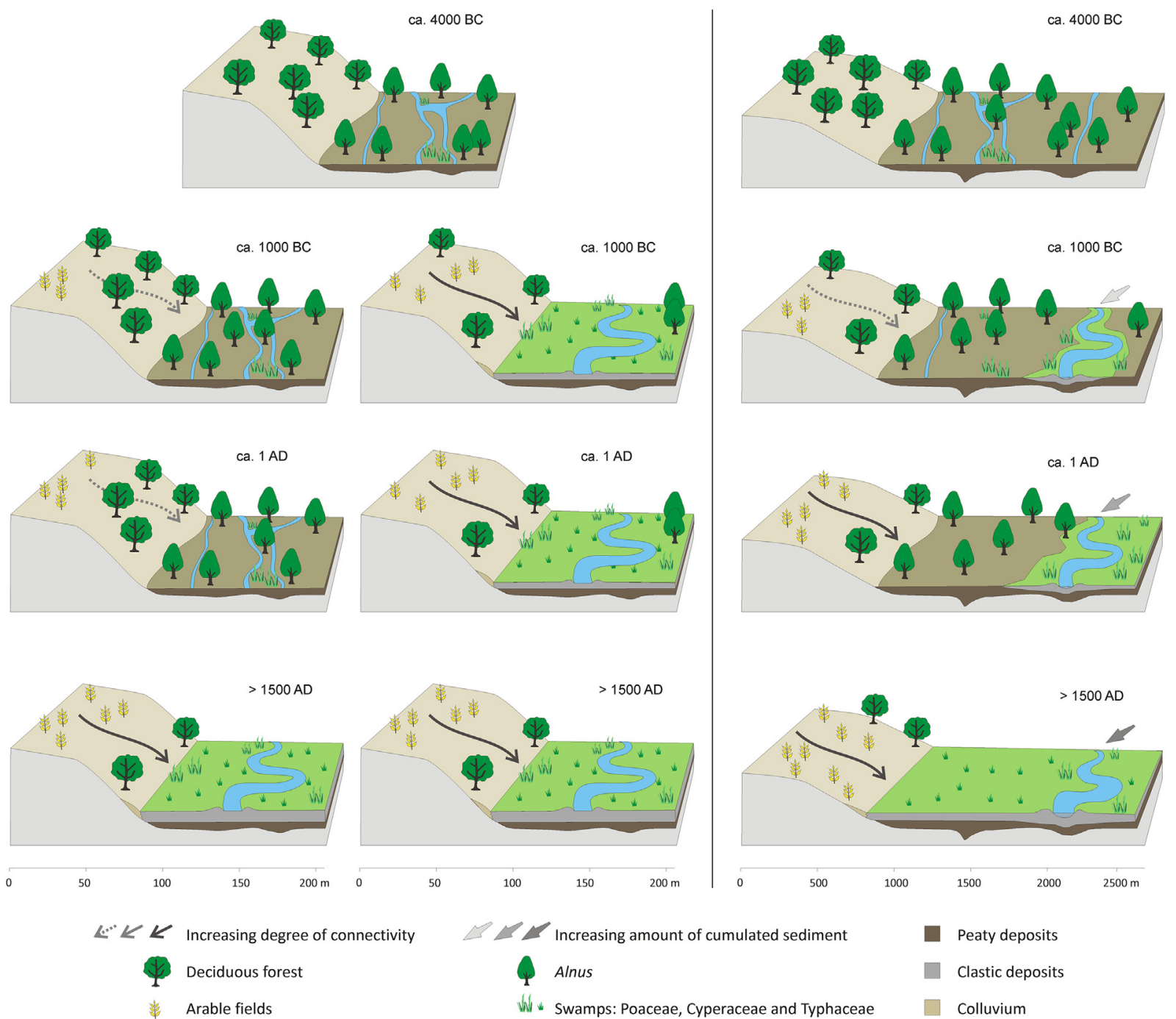

$50 \quad 100$

$100 \quad 150$

mulated sediment

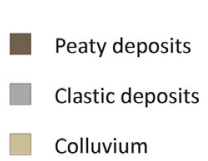

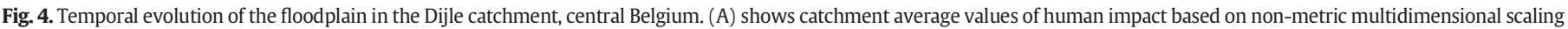

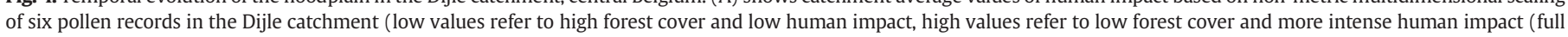

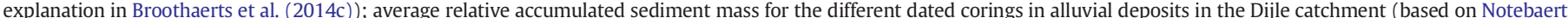

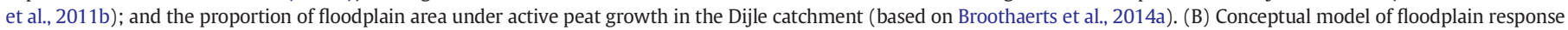

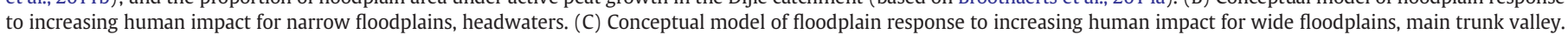
Panel B and C are reprinted from Broothaerts et al. (2014b), with permission from Elsevier. 


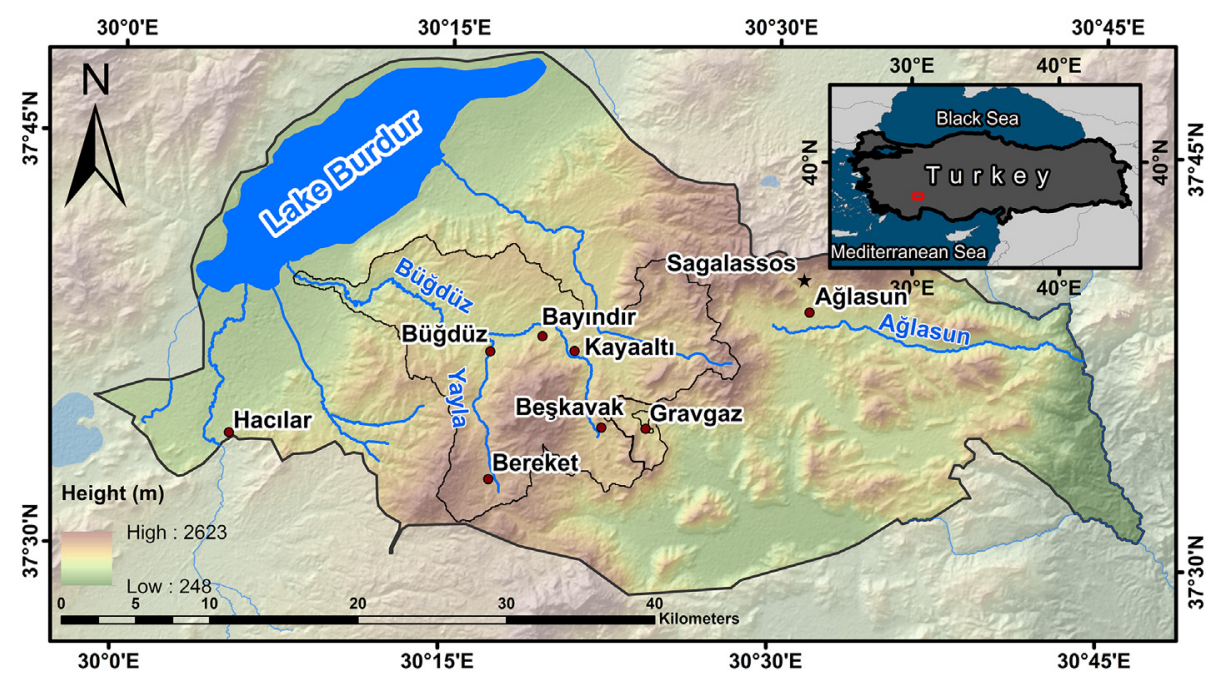

Fig. 5. Overview of the territory of the ancient city of Sagalassos, southwestern Turkey, with indication of the Büğdüz and Gravgaz catchments.

has been questioned by Chiverrell et al. (2011), it is still considered a robust methodology to investigate the general pattern of sediment dynamics at centennial timescales (e.g. Macklin et al., 2011; Dusar et al., 2012; Broothaerts et al., 2014a). Whilst PDFs show the periods with recorded sediment dynamics, Fig. 4A shows the relative accumulated sediment mass for the Dijle catchment throughout the Holocene. All sediment and radiocarbon ages were used to quantify the timedifferentiated Holocene sediment budget for the Dijle catchment (Fig. 2). The data show a continuous increase in alluvial sedimentation through time (Fig. 4A). However, it is clear from Figs. 2 and 3 that colluvial sediment deposition already reaches relatively high values in the period $2000 \mathrm{BC}$ to $1000 \mathrm{AD}$, whereas alluvial sediment deposition peaks during the last 2000 year. The transition from a wetland environment to a floodplain with a meandering river channel has been dated at 12 locations showing variability between the upstream floodplains and the main trunk valley downstream (Fig. 4).

\subsection{Southwestern Turkey}

Sagalassos is a classical city perched on a mountain slope in the Taurus mountain range, southwestern Turkey (Waelkens et al., 1999) (Fig. 6). The territory of Sagalassos ( $1430 \mathrm{~km}^{2}$ in Roman Period) comprises a patchwork of (semi-)closed basins bounded by steep limestone slopes, rolling landscapes with moderate slopes developed on marls, ophiolitic mélange, conglomerates, flysch or mudstone, but also wider, flat valley bottoms alternating with steep, incised, narrow river channels (Fig. 6). Although the plains surrounding Lake Burdur had already been occupied early in the Neolithic (de Cupere et al., 2015), the major occupation phase of the mountain regions was later during the so-called Beyşehir Occupation Phase (BOP) roughly coinciding with the Iron Age, Hellenistic Period and Roman Imperial Period (i.e., approximately $750 \mathrm{BC}-450 \mathrm{AD}$ ). Pollen records from various sites in the territory indeed reveal that human pressure was highest in the Roman Period (Bakker et al., 2012). Several catchments within the region have been the focus of archaeologic, geomorphic and pollen studies, in order to unravel the anthropogenic and climatic impact on the environment (e.g. Waelkens et al., 1999; Vermoere et al., 2002; Kaniewski et al., 2007; Bakker et al., 2011; Dusar et al., 2012; D'Haen et al., 2013). This study focuses mainly on the Büğdüz and Gravgaz catchments. The latter is a small $\left(11.4 \mathrm{~km}^{2}\right)$ endorheic catchment situated at an altitude of
1215-1550 m a.s.l. Although there is a small karstic outlet, the central marsh serves as a nearly perfect sediment trap for the soil eroded off the steep limestone slopes and the gullied slopes developed on ophiolitic mélange and flysch formations. Neo-tectonics play an important role in the development of the landscape of the Büğdüz catchment $\left(260 \mathrm{~km}^{2}\right)$ in the western part of the territory. Plio- and Pleistocene normal faulting created the Burdur graben to the northwest of the catchment and relative uplift of the catchment is on the order of several hundreds of meters (Fig. 6). Former lacustrine marls are now exposed in the western part of the catchment, whereas the limestone dominated Beşparmak mountain range dominates the eastern part. Neo-tectonic faulting along the mountain range triggered erosion of the mountain range and the deposition of thick coarse-grained deposits at the flanks. The limestone mountain range and underlying ophiolitic mélange are remnants of the Lycian Nappe (Miocene) which also dominates the Gravgaz catchment immediately east of the Büğdüz catchment. Rivers in the Büğdüz catchment are incised into the uplifted area. The length profile of the Büğdüz and its main tributary is characterized by several convexities that are related to the normal faults, showing that the river is not yet in equilibrium with tectonic processes (Fig. 6). In between the over steepened river reaches, relatively broad valley bottoms have developed such as near Bereket, Beşkavak and between Büğdüz and Bayinder villages. In the latter region (geomorphic zone 5 and 6 on Fig. 6A and C), several phases of cut-and-fill could be identified for the last 2000-3000 year (Fig. 7). At the outlet of the catchment, a large Quaternary alluvial fan has developed before the river enters Lake Burdur.

The chronology of sediment storage in the Sagalassos territory was established through 178 AMS radiocarbon ages, of which 110 are from the Büğdüz catchment and 33 from the Gravgaz catchment (Dusar et al., 2012). Fig. 3 shows the PDFs for colluvial sites, floodplains in the headwaters of the catchments and floodplains in the lower parts. All curves show a major peak in geomorphic activity in the Iron Age (750 $\mathrm{BC}-333 \mathrm{BC}$ ), which is only surpassed in extent in the lower valleys during the last few centuries. Fig. 8 gives an overview of the sediment chronologies for the Gravgaz catchment and for three sites in the Büğdüz catchment. Here as well, a sharp increase in sedimentation rate can be seen during the Iron Age. Based on 10 corings in the Gravgaz marsh, total sedimentation volumes could be reconstructed at a high temporal resolution using 33 AMS radiocarbon ages. These dates were used to

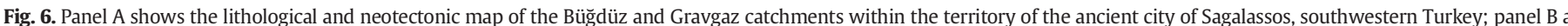

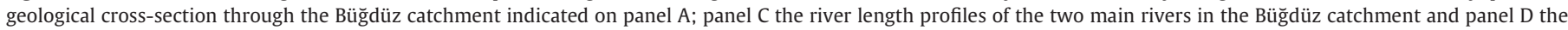

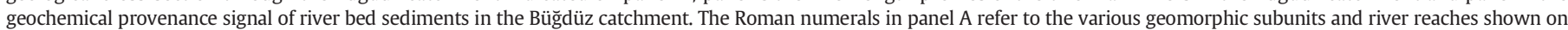
panel C and D. All figures are reprinted from D'Haen et al., 2013, with permission from Elsevier. 
A
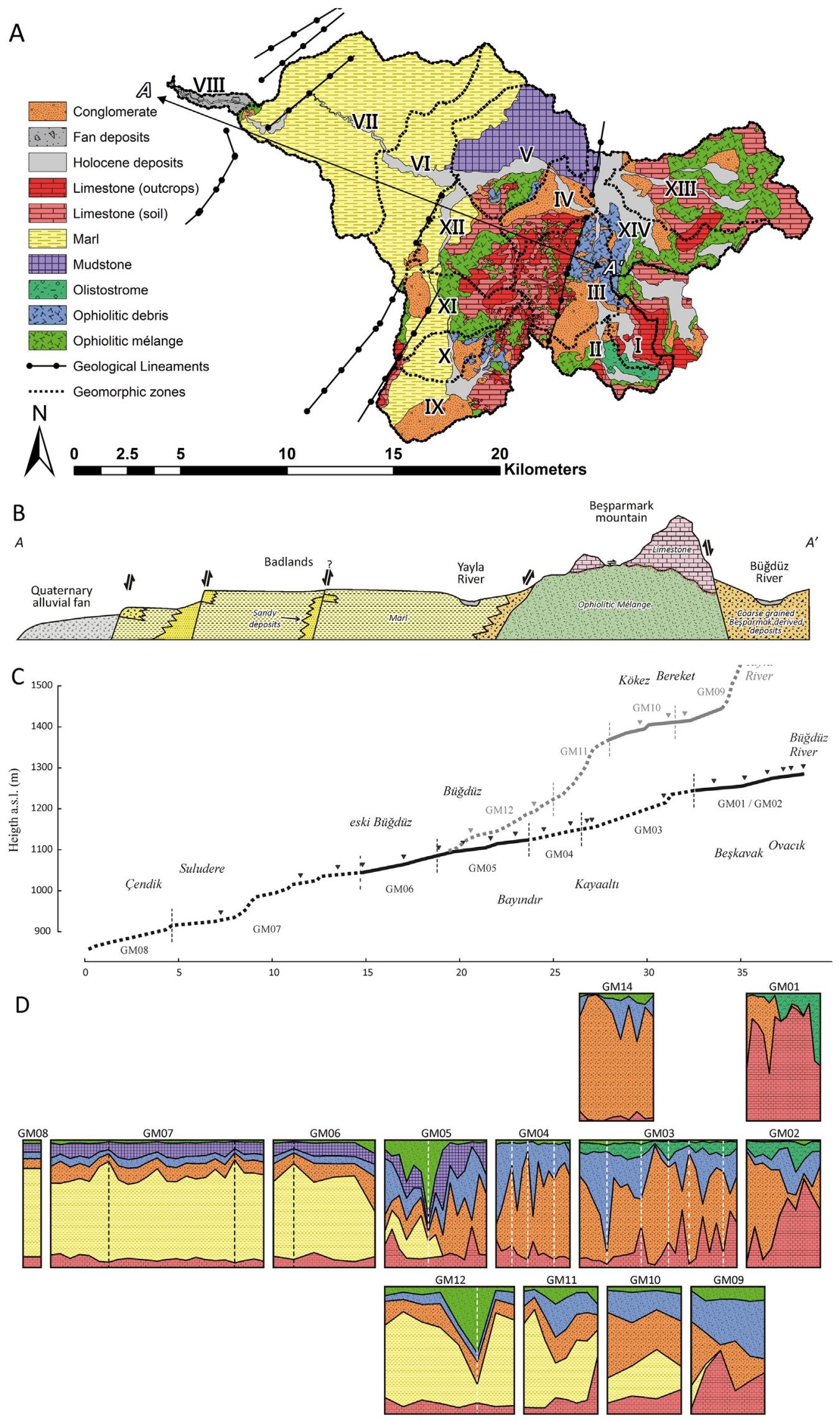

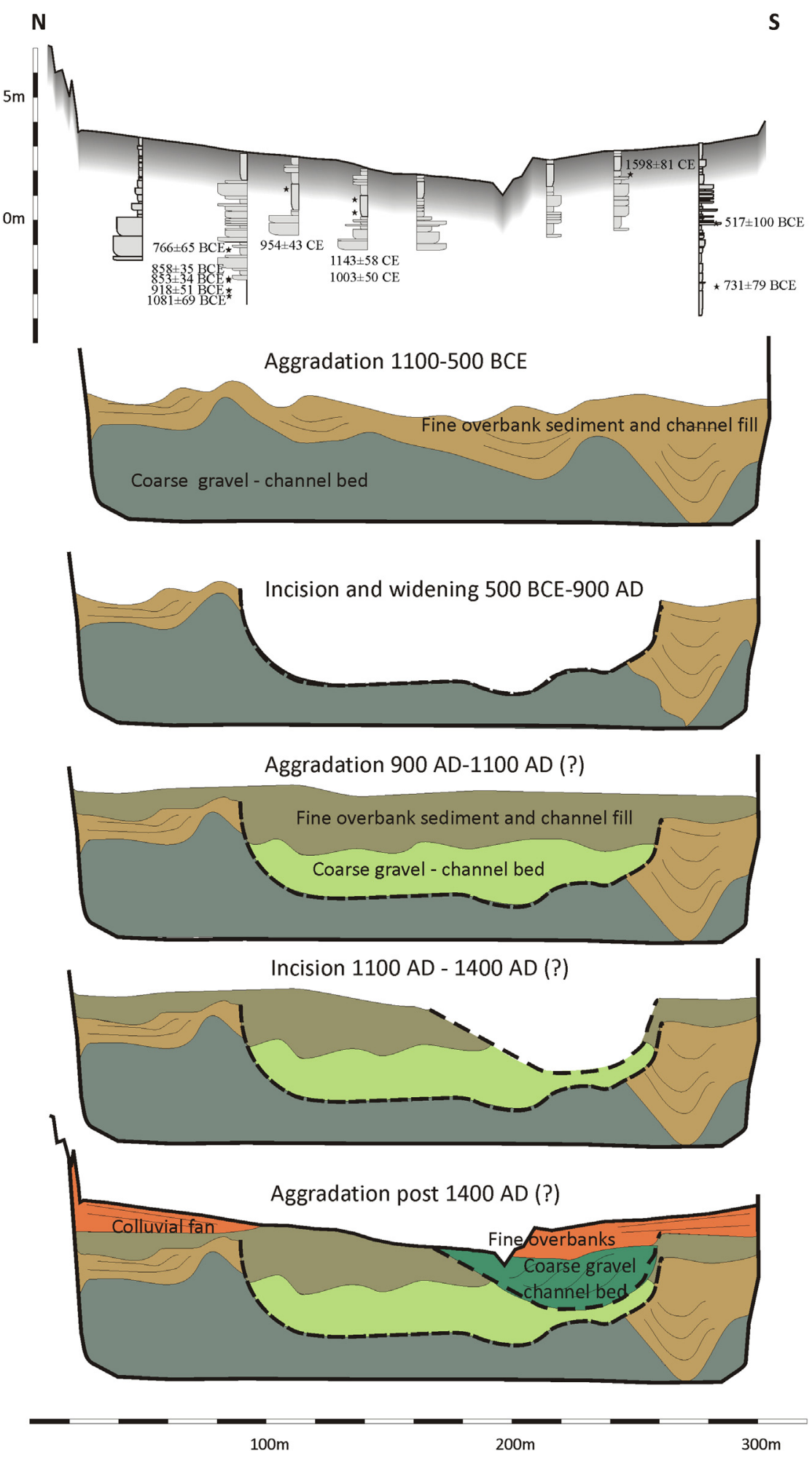

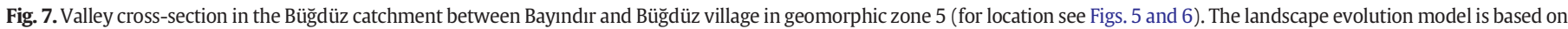
sediment stratigraphy and 11 AMS radiocarbon ages (based on Dusar, 2011; D'Haen, 2012a). Exact timing of aggradation and incision phases is uncertain up to 100-200 year.

calibrate the spatially distributed soil erosion and sediment delivery model WaTEM/SEDEM for the last 4000 year using a pollenbased C-factor as a proxy for human pressure (Van Loo et al., 2017) (Fig. 9). Since the catchment is endorheic, total sediment volumes equal total erosion volumes, and hence, the original soil thickness cover could be reconstructed. We should note that we only considered erosion and deposition of clastic soil material, i.e., bed and suspended load, and not the dissolved load. The latter may be equally important given the karstic nature of the limestone in the catchment. However, we believe that limestone dissolution is especially important in the subsurface and that it does not impact changes in soil thickness, soil erosion or sediment deposition at the timescales under consideration. Average soil carbonate concentrations for hillslopes and depositional environments are also similar (D'Haen, 2012), suggesting no net loss of carbonates between hillslopes and valleys. 

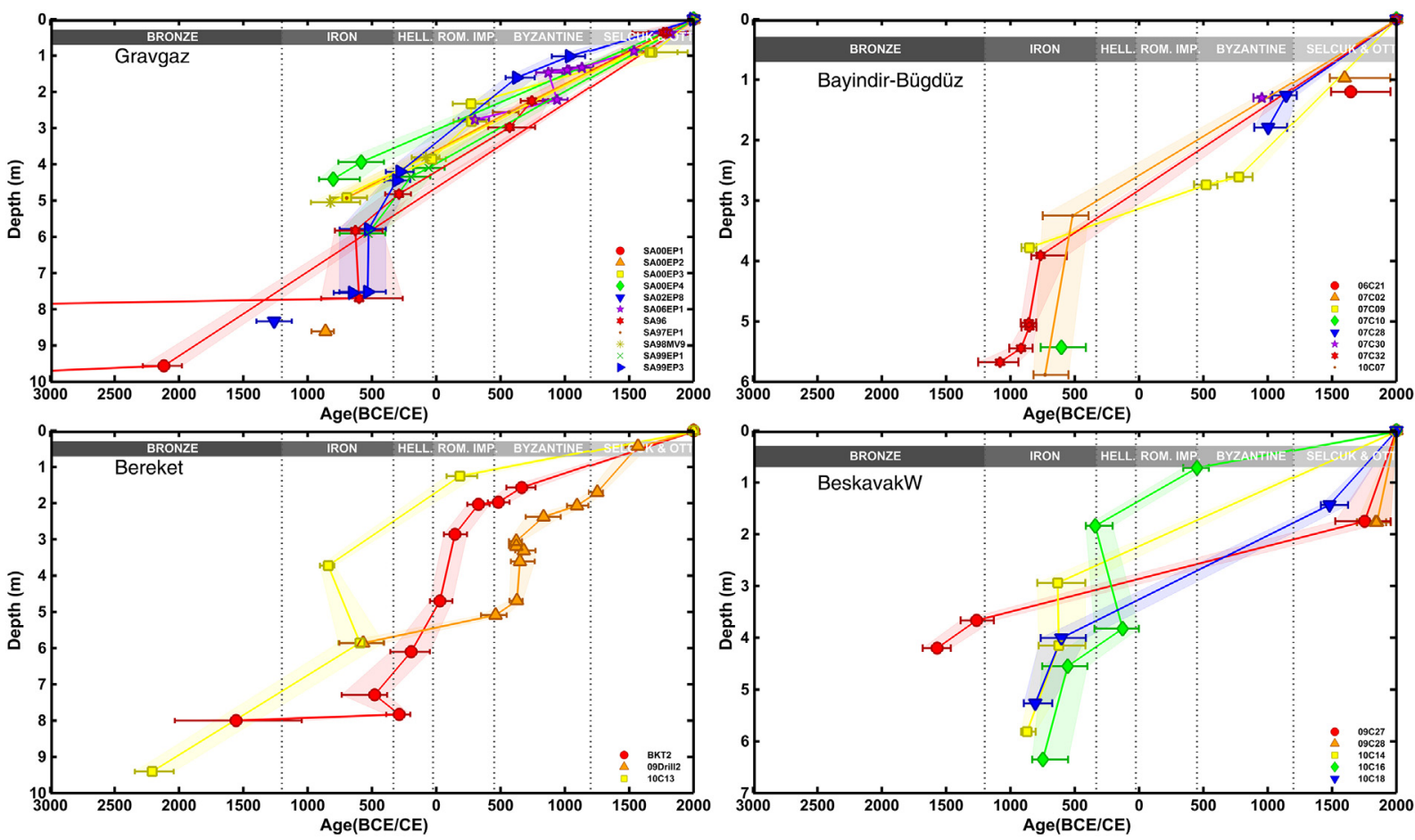

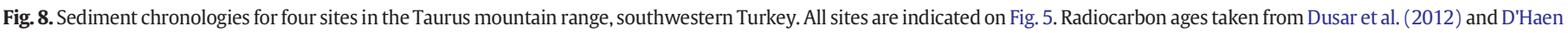
et al. (2013).

A geochemical sediment fingerprinting approach was used to identify the sediment sources in the Büğdüz catchment (D'Haen et al., 2012; D'Haen et al., 2013). Fig. 6 shows the provenance of fine sediment sampled from the contemporary channel with regular intervals of 200-300 m. Comparison with the lithological map (Fig. 6) shows a close correspondence between local lithology and sediment provenance suggesting that local sediment sources are important.

\subsection{USA}

The impact of humans on fluvial sedimentation is probably nowhere as clear and well documented as in the United States. The impact of Euro-American agricultural land use on fluvial sedimentation has been demonstrated in many river catchments throughout the eastern and midwestern US. The seminal work of Happ et al. (1940) on accelerated stream and valley sedimentation in the loess areas of northern Mississippi was later followed by detailed studies in, amongst others, the Driftless Area and Upper Mississippi Valley in Wisconsin, Iowa, Illinois and Minnesota (Happ, 1944; Knox, 1972; Knox, 1977; Trimble, 1981; Trimble, 1983; Magilligan, 1985; Knox, 1987; Beach, 1994; Trimble, 1999), the southern Piedmont (Happ, 1945; Trimble, 1974) and in the Appalachian Blue Ridge Mountains (Leigh and Webb, 2006; Royall and Kennedy, 2016). Early accounts of accelerated erosion following the arrival of European settlers in the 18th and particularly the 19th century are numerous (for an overview see Dotterweich, 2013). For instance, early farmers in the eastern states including US Presidents Washington and Jefferson, were aware of the devastating impact of soil erosion on farmland (Bennett, 1944; Montgomery, 2007a). Thomas Jefferson commented in 1817 that "fields were no sooner cleared than washed" (Hall, 1937; p.5). With the expansion of agriculture towards the west in the 19th century, local reports on intense erosion processes start to appear also in the southern Piedmont (see Trimble, 1974), in Mississippi (e.g. De Bow, 1853; Lowe, 1910) as well as in the Driftless Area (see Trimble, 2013). Historical information on land-cover changes for the southern Piedmont (Trimble, 1974) and Coon Creek, Wisconsin (Trimble and Lund, 1982; Trimble, 1983; Trimble, 1999; Trimble,
2013) showed that erosive land use peaks from the second half of the 19 th century to the early 20th century (Fig. 10). A decline in erosive land use can be observed in many regions from the 1920s and 1930s onwards, which is to some extent related to the increasing awareness of the soil erosion problem and the implementation of soil conservation measures (Bennett, 1928; Bennett, 1939), but also to the fact that many highly degraded soils were left and became reforested. Peak rates in stream valley sedimentation were observed mainly in the early 20th century, often several decades after the first peaks in erosive land use (Coon Creek, Trimble and Lund, 1982) (Fig. 10). For Coon Creek $\left(360 \mathrm{~km}^{2}\right)$, Trimble $(2010,2013)$ showed that tributary valleys experienced major sedimentation around the turn of the 19th to 20th century, whilst sedimentation in downstream valleys peaked in the 1920-1930s (Fig. 11). The downstream valley of the Grant River (approximately $600-700 \mathrm{~km}^{2}$ ) in Wisconsin even showed a peak in sedimentation as late as the 1940-1950s (Fig. 12A and Knox, 2006), whilst sedimentation rates in a floodplain lake (Lake Pepin) within the Upper Mississippi Valley only started to peak in the 1940s and did not decrease until after that (Fig. 12B and Belmont et al., 2011). Geochemical fingerprinting of the sediments in Lake Pepin and in the tributary La Sueur catchment $\left(2880 \mathrm{~km}^{2}\right)$ in Minnesota showed that upland topsoils were the peak contributor of floodplain aggradation until the 1940-50s but in more recent decades river banks became the main sediment source (Fig. 12B).

\section{Factors controlling the geomorphic response to anthropogenic disturbance}

The three different case studies all have experienced, or still experience, intense human pressure on the environment through deforestation and consequent crop cultivation and/or grazing practices. However, the response of the hillslope-fluvial system is quite different in several aspects. Fig. 13 illustrates the temporal evolution in relative sedimentation rates for the three case studies. Where the sedimentation rate for the Dijle catchment shows a continuous increase, both the Büğdüz and the upper Midwest US catchment show a sediment wave, albeit in different periods. The next paragraphs discuss several factors 

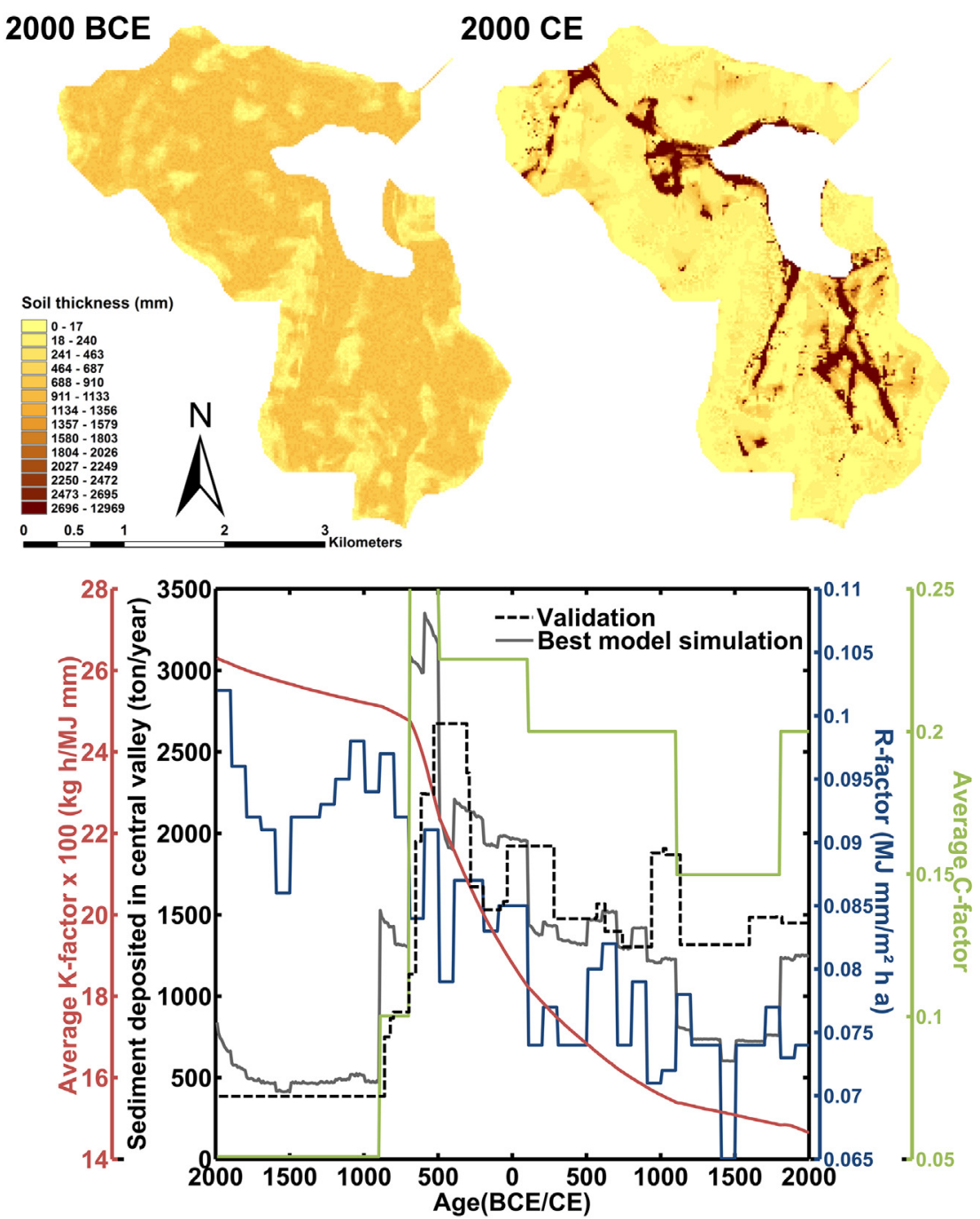

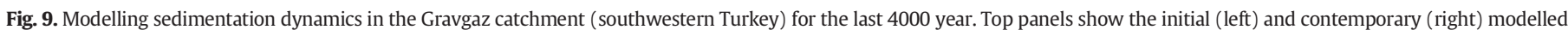

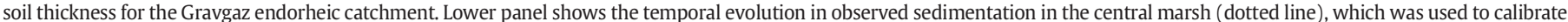

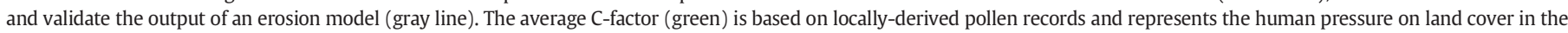

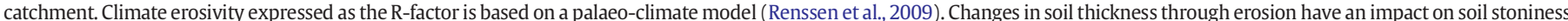

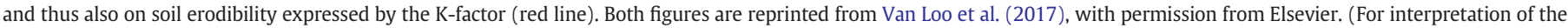
references to colour in this figure legend, the reader is referred to the web version of this article.)

controlling the geomorphic response to human impact. The variability in geomorphic response is illustrated by the conceptual diagram shown in Fig. 14.

\subsection{Timing and duration of human pressure}

Global reviews of anthropogenic land use show that the timing of the first significant human land use goes back 8000 year BP or more in centers of agricultural origin such as the Near East, but only 100200 year in large parts of the Americas, Africa, Australasia and central Asia (Kaplan et al., 2011; Ellis et al., 2013). However, land-use history does not follow a linear trajectory, and indeed many regions have experienced several phases of population growth and decline, and in return also waves of human pressure on the environment. This ultimately also has its implications on sediment delivery to the fluvial system.

Between the three case studies major differences exist in timing and duration of significant human pressure. The Dijle catchment has experienced human pressure for $>5000$ year and it gradually increased throughout time (Fig. 4A). Nearly complete deforestation typified the catchment since the High Middle Ages (1000-1200 AD) and only in the last century a decrease in cropland cultivation took place. As a result of the nearly continuous increase in human pressure, there has been a continuous and increasing input of sediment into the fluvial system (Figs. 4A and 13). The sediment chronology indeed shows that erosion and sediment deposition increased through time following the increase in human pressure. Similar observations have been made for other loess catchments in central and northwestern Europe (Macaire et al., 2002; de Moor et al., 2008; Dotterweich, 2008; Fuchs et al., 2010; Notebaert and Verstraeten, 2010; Houben et al., 2013).

For the mountainous Mediterranean catchments in southwestern Turkey, however, human pressure fluctuated through time with the highest intensities recorded during the Beyşehir Occupation Phase (BOP), roughly coinciding with Hellenistic and Roman Imperial Period. Several cycles of agricultural expansion and contraction followed this phase but only during the last two centuries human pressure through deforestation, crop cultivation and grazing practices reached values as high as during the BOP (Bakker et al., 2012). Sediment input into the fluvial system therefore has changed as well with several pulses of aggradation and incision. For the Büğdüz River catchment, fluvial sedimentation indeed peaked during the onset of the BOP but also during the last two centuries more fluvial activity and higher sedimentation rates could be observed (Figs. 3, 8, and 13). Few sediment ages are 


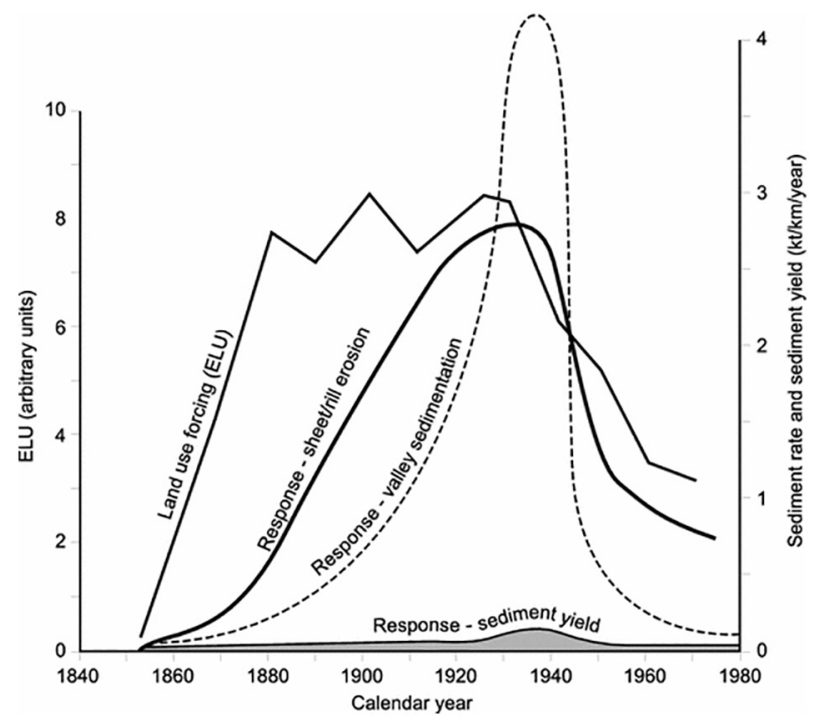

Fig. 10. The land use, erosion and valley sedimentation history of Coon Creek, Wisconsin since 1853 (Dearing et al., 2006 based on Trimble and Lund, 1982). Reprinted from Dearing et al., 2006 with permission of Springer.

obtained for the intermediate periods suggesting that in these periods of lower human pressure and sediment delivery, rivers mainly removed sediments through lateral activity and incision as is shown for the floodplain cross section between Büğdüz and Bayındır (Fig. 7). Similar observations were made not only in other regions in the Eastern Mediterranean (for a review see Dusar et al., 2011) such as in the Southern Argolid, Greece (van Andel et al., 1986) or the Drama plain in northeastern Greece (Lespez, 2003), but also in the Western Mediterranean such as in southeastern Spain (for a review see Bellin et al., 2013), Northern Africa (e.g. Faust et al., 2004) or Southern France (e.g. Notebaert et al., 2014). For most Mediterranean catchments we observe, indeed, several phases of human impact and consequent geomorphic activity with the highest intensities often during the Roman Period and again increased rates in the last few centuries.

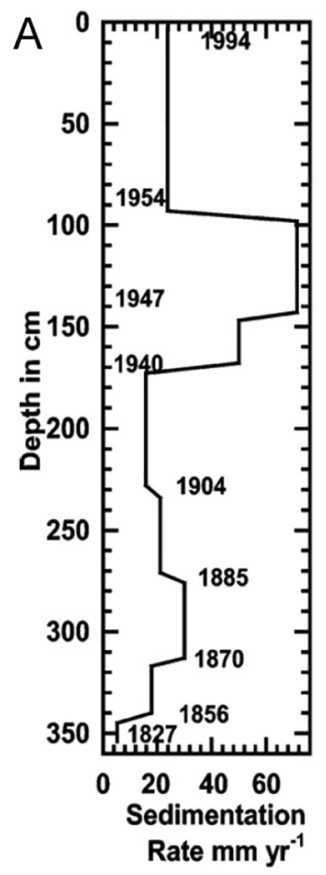

$\mathrm{B}$

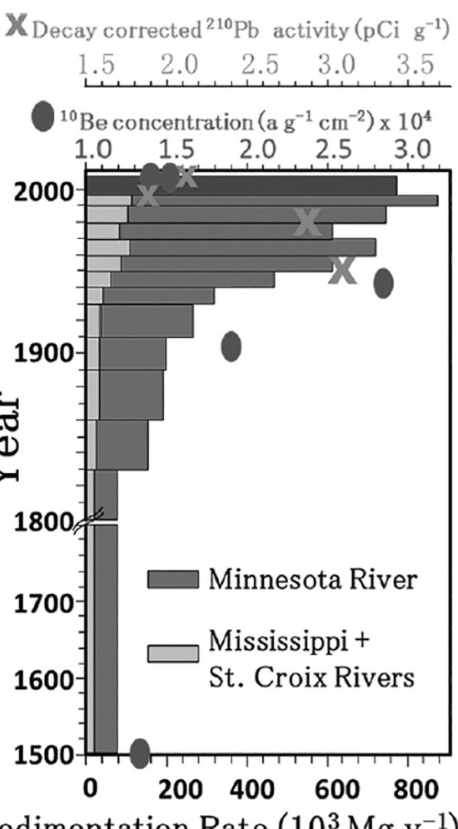

Fig. 12. (A) Floodplain sedimentation rate for Grant River, Wisconsin (Knox, 2006); (B) Sedimentation history of Lake Pepin in the Upper Mississippi Valley (Belmont et al., 2011). High concentrations of radionuclides $210 \mathrm{~Pb}$ and $10 \mathrm{Be}$ point to a high contribution of topsoil material, whilst lower concentrations suggest a higher input from the subsoil such as river banks.

The most prominent examples of short-lived sediment waves are the many catchments in the New World such as the USA or Australia. Despite the fact that there is growing evidence that also native cultures in North America impacted their environment through deforestation and consequent soil erosion in some areas (Delcourt and Delcourt, 2004; Stinchcomb et al., 2011; Dotterweich et al., 2014), major human pressure is still largely confined to the first century following

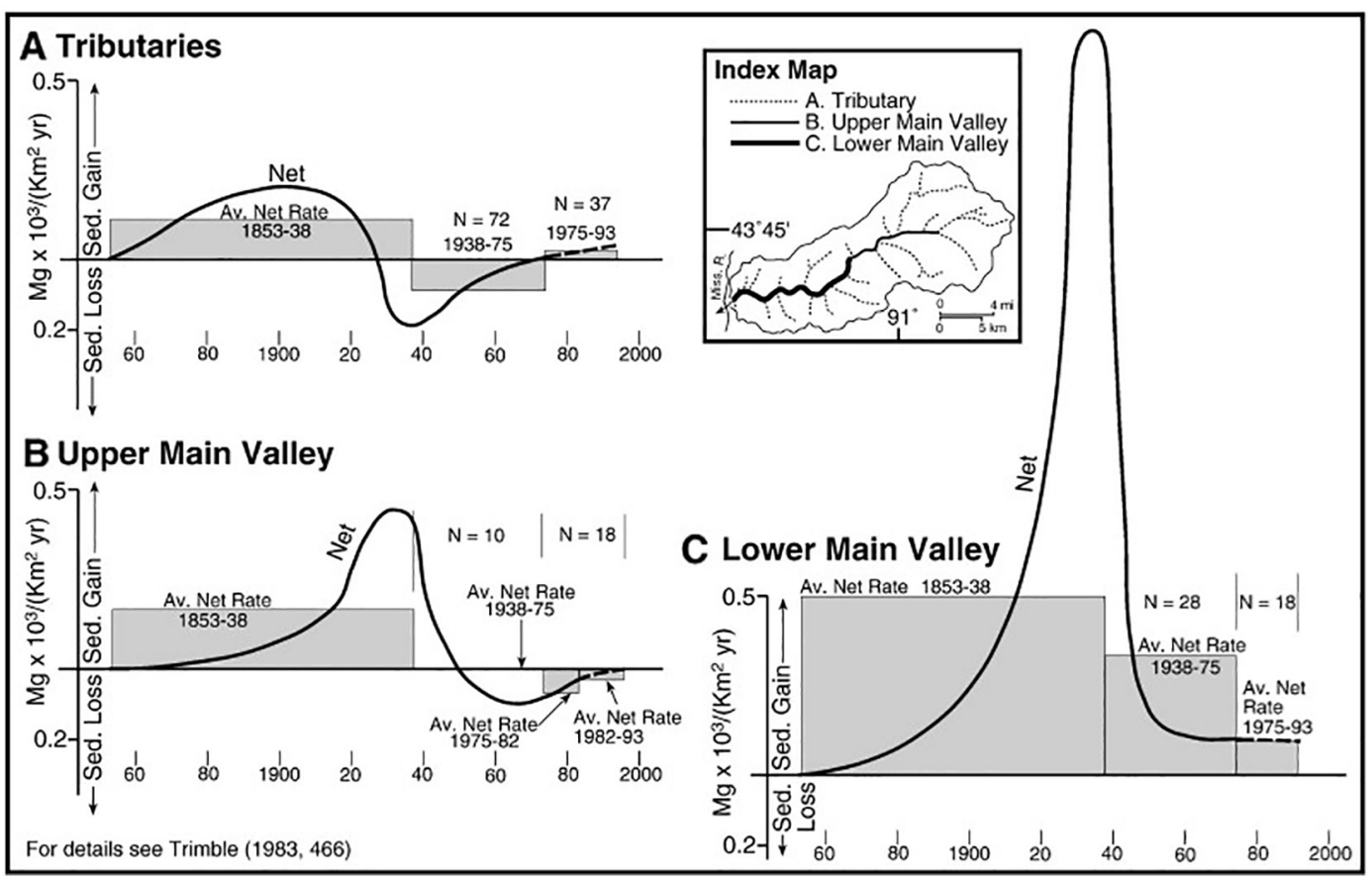

Fig. 11. Variability in floodplain sediment storage within Coon Creek, Wisconsin 1853-1993. Reprinted from Trimble (2009) with permission from Elsevier. 


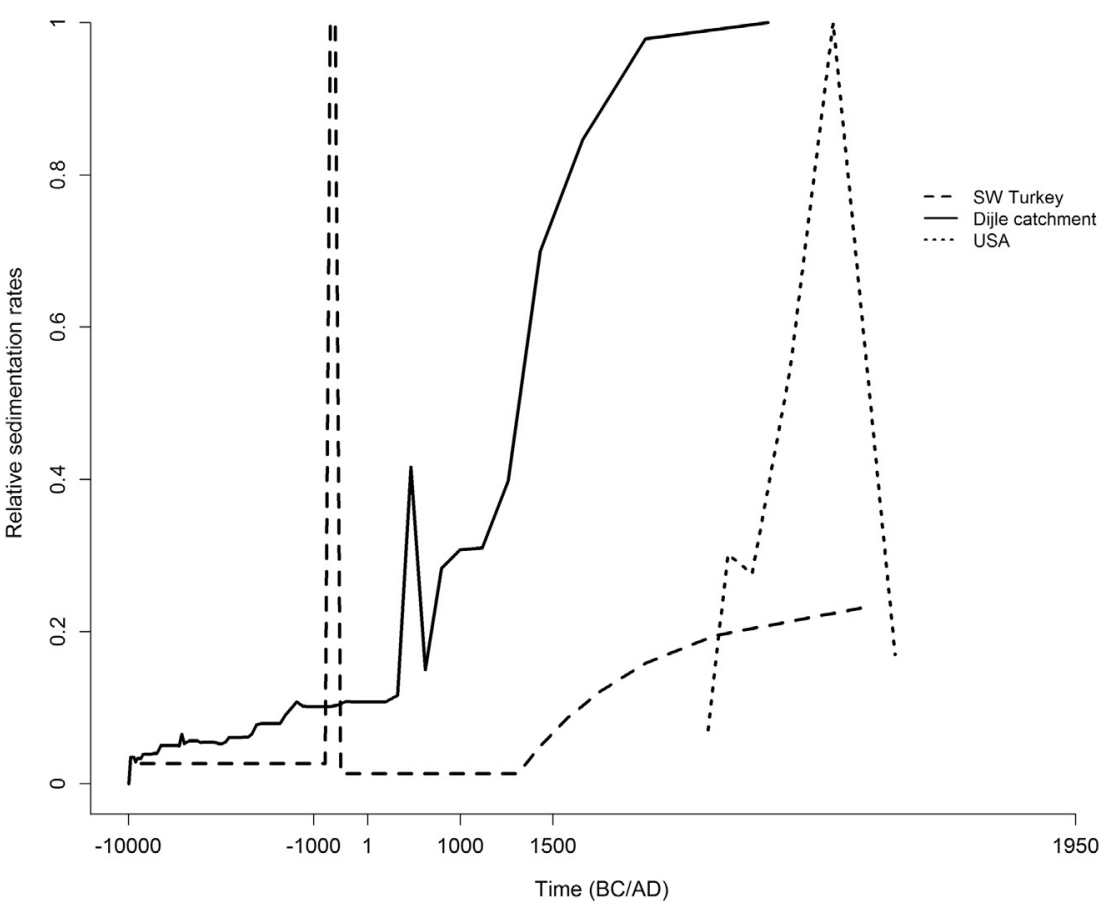

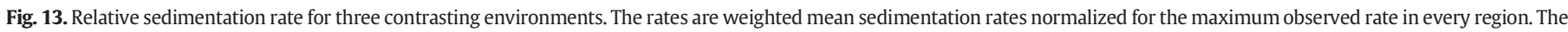

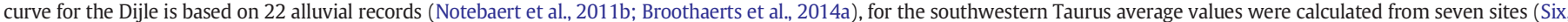

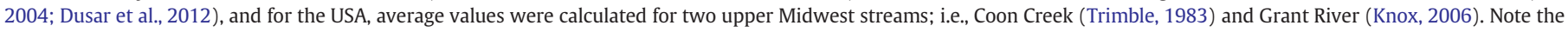
non-linear (logarithmic) time scale.

colonization by European settlers (James, 2011). Both in the USA and in Australia, the massive deforestation and expansion of crop cultivation soon led to severe soil degradation that either triggered land abandonment, reforestation and/or the implementation of soil conservation techniques. Sediment delivery from hillslopes therefore declined rapidly (Figs. 10, 13, and 14) and rivers responded by removing the legacy sediment through incision and increased lateral activity, which has become one of the main sediment sources in many river systems (e.g. Trimble, 1974; Meade, 1982; Simon and Rinaldi, 2000; Walter and Merritts, 2008) (Fig. 12).

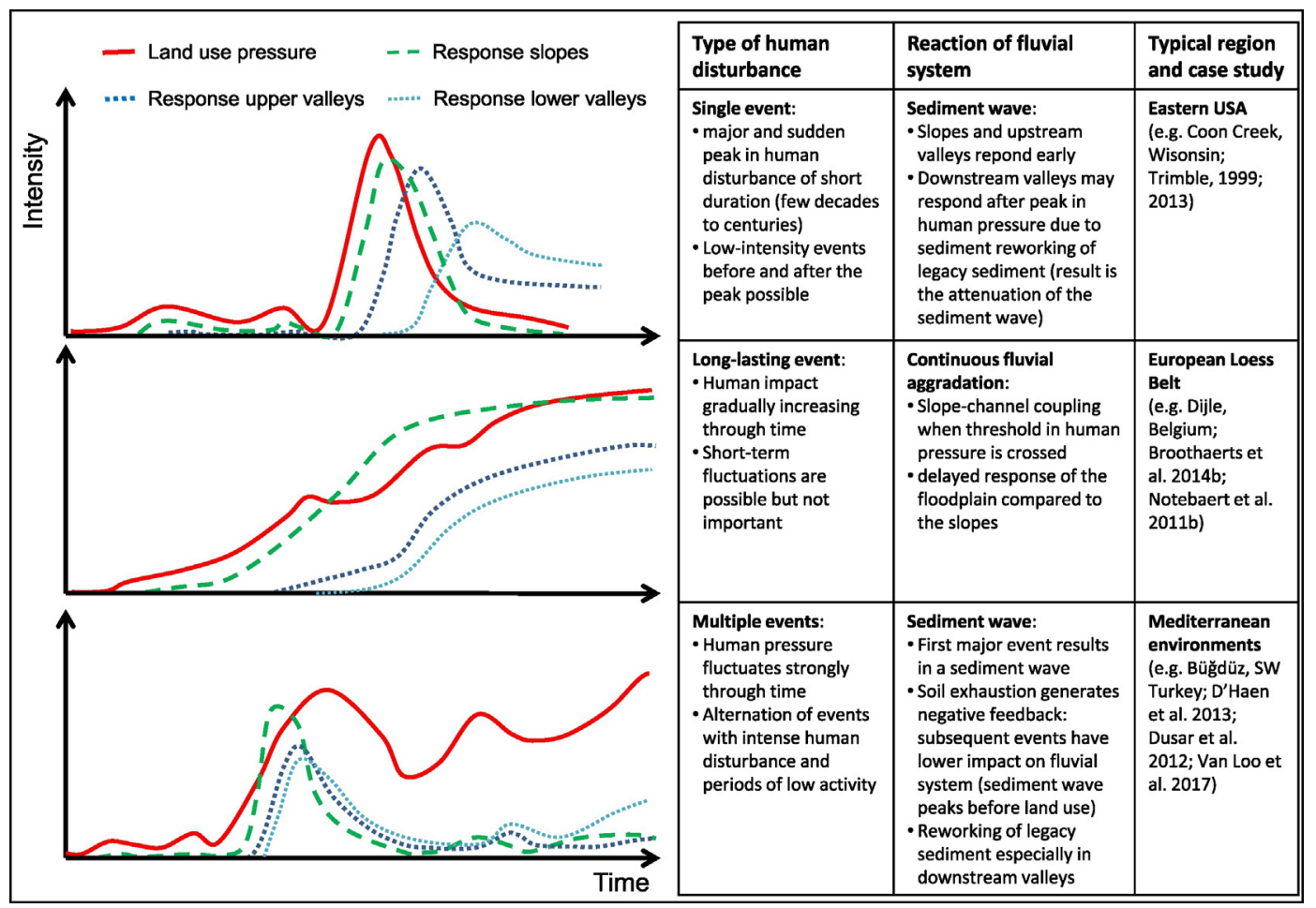

Fig. 14. Conceptual diagram showing the variability in geomorphic response following human disturbance. Note that the three time axes are not necessarily synchronous. 


\subsection{Existence of feedback mechanisms}

The evolution in erosion and sediment delivery in southwestern Turkey does not correspond as well to human pressure as was observed for the temperate Dijle catchment. Peaks in hillslope sediment delivery take place mainly during the Iron Age (approximately 1000-500 BC), well before the heydays of the classical city of Sagalassos during the Hellenistic and Roman Imperial Periods (333 BC-300 AD) (Fig. 8). The peak corresponds only to the onset of the $\mathrm{BOP}$, not to its complete duration (see also Fig. 14). The temporal sediment budget and geomorphic modelling results for the endorheic Gravgaz catchment show that the first major clearings of the forest on the steep slopes triggered such intense erosion that soil thickness was drastically reduced in a short time span (Fig. 9). Hence, stoniness of the topsoil increased and as a result the erodibility of the remaining soil cover declined, i.e., a negative feedback. Soil erosion levels therefore dropped by approximately $30 \%$ within $<300$ year whereas human pressure did not change significantly. In addition, crop yields from the hillslopes dropped due to the reduced soil thickness (Van Loo et al., 2017). We argue that major human pressure through intense crop cultivation since then was mostly restricted to the relatively gentle sloping to nearly flat valley bottoms and intramontane basins where crop productivity was still sufficiently high. During the Mid-Byzantine (11th century AD) and Ottoman Periods (15th century $A D$ ), short periods of increasing human pressure in the mountain regions did not result in a significant increase in sediment delivery as the slopes were already deprived of their readily erodible soil cover (Fig. 14). The loss of soil cover through anthropogenic erosion in the Mediterranean has been described by Greek and Roman writers (Montgomery, 2007a), 19th and 20th century scholars (e.g. Lowdermilk, 1953), and documented through a growing number of geoarchaeological studies such as the classical work of van Andel in the southern Argolid (van Andel et al., 1986).

Such feedback mechanisms do not play a significant role within the Dijle catchment. Here, loess soils are much deeper and although soil erosion can be quite intense (i.e., up to $2 \mathrm{~m}$ on some steeper slopes), the remaining loess cover is still thick enough to sustain crop cultivation in a high-intensity agricultural system (i.e., with application of manure and chemical fertilizers). Only on some steeper slope segments and convexities have the underlying sands outcrop and land use been converted in historical times from cropland to forest. In some central European loess catchments, however, loess soils are relatively thin and underlain by less fertile and less erodible bedrock. Bronze age human impact at the Frauenberg site in southeastern Germany, for instance, was already sufficiently high such that the thin loess cover eroded off the slopes which resulted in a return to forested conditions lasting up until present (Lang et al., 2003b).

For many regions in the New World that experience intense soil degradation following the arrival of European colonizers, a return to forest cover and hence a reduction in soil erosion and sediment delivery can be observed within a few decades (Williams, 2003) (Fig. 10). In most cases this decline in erosion is not related to a sudden decrease in soil erodibility, but rather to a strong decrease in soil chemical productivity and/or the physical ruination of the land through intense gullying making the land unsuitable for further crop cultivation (e.g. Lowe, 1910; Trimble, 1974; Montgomery, 2007a).

Thus, a direct negative feedback between soil thickness and soil erosion can be observed for the Mediterranean mountain catchments, rendering the landscape less susceptible to human pressure. For areas with thicker soil profiles such as the loess regions in Europe or the USA, this direct feedback is not relevant but rather an indirect feedback can be observed: human pressure increases soil erosion to a level that the land no longer becomes attractive for farming leading to a decrease in human pressure, and hence soil erosion declines (typical for many regions in the USA or for some central European landscapes). However, a renewed increase in human pressure through deforestation would again lead to high erosion rates as an erodible soil cover remains. Or, as is the case for central Belgium, sustained agriculture results in sustained high levels of erosion and sediment delivery (Fig. 14).

\subsection{Thresholds and tipping points}

All case studies illustrate the existence of threshold levels of human impact and in some cases even real tipping points. For the Dijle catchment, the sudden increase in floodplain sediment storage during the last 1000 year is much more pronounced than the increase in human pressure may suggest. Whereas the average erosion rate increased seven-fold during the last 1000 year compared to the period 2000 BC-1000 AD, colluvial deposition increased five-fold but floodplain aggradation nearly twelve-fold (Fig. 2). Furthermore, the PDFs (Fig. 3) show that floodplains respond later than hillslopes. Hypothetically, a threshold level in human pressure needs to be crossed before floodplains receive significant amounts of sediment, whereas slopes trap sediment at lower intensities of human pressure. Similar to Lang et al. (2003a) this is attributed to changes in slope-channel coupling, but also to changes in settlement location. Up until the Roman Period, settlements and cultivated land were either fragmented or located on the higher plateau slopes (Verstraeten et al., 2009). Sediment eroded off the tilled land was trapped in the many forest patches that still exist, especially along the steeper slopes in between the plateau and the channel-floodplain system (Fig. 4, early periods). However, from the early Medieval Period onwards, settlements moved to the floodplain edges and especially with the widespread deforestation in the High Middle Ages, forest patches on the slopes were cleared and cultivated slopes were now better connected with the fluvial system (Fig. 4, later periods). Fig. 15 shows results of a spatially distributed soil erosion and sediment transport model applied to the Dijle catchment whereby the sediment delivery from hillslopes to river channels increases nonlinearly with increasing area under cropland, thus illustrating the slope-channel threshold concept (De Brue and Verstraeten, 2014). We see that especially hillslope sediment delivery to the fluvial system increases sharply when at least $60 \%$ of the catchment is under cultivation, which became the case during the last 1000 year.

The evolution of the Dijle floodplain also shows the existence of a tipping point. Throughout the catchment a transition is observed from a wetland environment dominated by alder carr forest, no major river channel and net peat accumulation, to a single-thread meandering channel with cohesive banks, levees and an aggrading floodplain (Fig. 4; Broothaerts et al., 2014b). This transition took place within a relatively short time span for the smaller tributary river floodplains $(<300$ year) but rather gradually in the downstream trunk valleys ( $>2000$ year). The timing of the transition, which was determined by

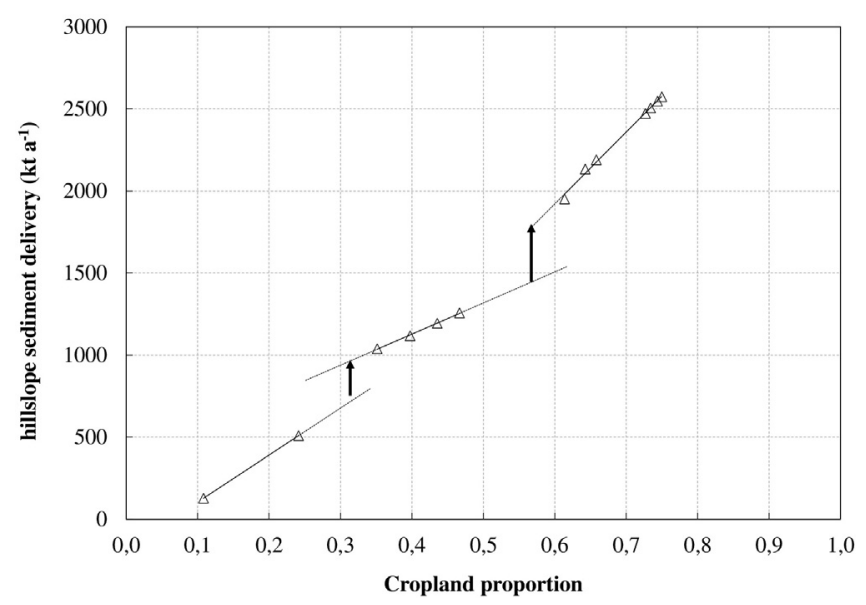

Fig. 15. Non-linear relation between fraction of cropland in the Dijle catchment and sediment delivery from hillslopes to the fluvial system (updated from De Brue and Verstraeten, 2014). 
dating the top of the peat layer, also differs between valley segments (Fig. 4). Fig. 4B shows that some valleys were already transformed well before the major sediment input of the Middle Ages. Only a minimum amount of mineral sediment input resulting from anthropogenic soil erosion appears to have been enough to stop peat growth and to develop a permanent river channel with fine-grained cohesive banks. Experimental studies indeed show that sedimentation of cohesive sediment is needed to initiate and maintain meandering river channels (Dijk et al., 2013). The spatial variability in floodplain response thus corresponds to the first important local signs of human pressure whereby slopes and channels got connected, not necessarily to its maximum pressure. For the downstream trunk valley, cumulative sediment input from upstream tributaries already triggered this major geomorphic change approximately 3000 year ago, well before local slopes got connected (Fig. 4C).

Another major tipping point can be observed in the southwestern Taurus. As discussed above, soil stripping following the first important forest clearance resulted in a strong decrease in soil erodibility, and hence lower subsequent erosion rates. Such a reduction in hillslope sediment production is irreversible, which is not the case for the Dijle and US catchments.

\subsection{Landscape sensitivity}

The geomorphic response is defined by both human impact in the landscape and the sensitivity of the landscape to disturbance. Consequently, the variability in geomorphic response is to a large extent related to the landscape sensitivity. Scale definitely plays a role and several studies have shown that the response of the fluvial system to anthropogenic pressure decreases with increasing catchment size (e.g. Vanmaercke et al., 2015). For larger catchments, the buffering capacity increases and any disturbance signal of relatively short duration is damped within the system itself (Dearing et al., 2006; Wittmann et al., 2010). However, when considering smaller to medium-sized catchments (100-1000 $\mathrm{km}^{2}$ ), differences in environmental setting become more important. The role of soil characteristics (erodibility and thickness) has been discussed before (see section 3.2): catchments with thick erodible soils will be much more sensitive to human impact compared to catchments with less erodible or thin soil covers.

The geomorphic setting of the catchment also plays an important role. The Dijle catchment is a typical example of a relatively mature catchment with graded river longitudinal profiles. No major knickpoints can be observed along the River Dijle or its tributaries and withinchannel connectivity is relatively high. Furthermore, there are no major breaks in slope and slope-channel coupling is only influenced by land-cover patterns and intensities of anthropogenic land use (see section 3.1) but not to intrinsic geomorphic conditions. Total sediment accumulation in the floodplain therefore increases in the downstream direction as upstream catchment area increases (Notebaert et al., 2010) and the sediment archive in the downstream floodplain therefore in general is relatively well representative of the average human pressure in the catchment (Fig. 4).

The situation is, however, much different for the Büğdüz catchment in southwestern Turkey. Here, several smaller intramontane basins around Bereket and Beşkavak are major depositional centers (Fig. 6). River long profiles are not graded but instead several convexities and knickpoints can be identified (Fig. 6C). Within-channel coupling is high for the steep river reaches but very low to non-existent for the gently sloping river gradients draining the intramontane basins (Fig. 16). The geochemical provenance of sediments shows that most of the bed sediment is of local origin (Fig. 6D). Major sediment sources are the intensively-gullied marl badlands in the western part of the catchment and the ravines on the east flank of the Beşparmak mountain range dominated by poorly to non-consolidated gravel deposits and conglomerates (Fig. 6). These gully systems show a much better connectivity with the fluvial system than the cultivated slopes in the upstream parts of the catchment dominated by limestone and olistostrome (Fig. 16), hence the large variability in sediment provenance in geomorphic zones 2, 3 and 4 (Fig. 6D). The geomorphic setting of the western part of the Büğdüz is largely controlled by Neogene tectonics (Price and Scott, 1991; Sintubin et al., 2003). Ongoing uplift of the semi-graben near the outlet and subsidence of the Burdur basin resulted in a convex river long profile (Fig. 6). Here, geomorphic fluvial activity and sedimentation rates have been relatively high for the last two centuries (Fig. 3E). During periods of lowered human pressure, rivers again incised into the aggraded floodplain, followed by lateral activity that removed part of the anthropogenic sediments. Every new sediment pulse, related or not related to a new wave of human impact, will result in a rapid aggradation of the incised channel, hence the high rates for the most recent period (Fig. 3). In the mid-section of the catchment, the alternation of incision, lateral activity and aggradation is more or less balanced resulting in a relatively broad floodplain seemingly of the same

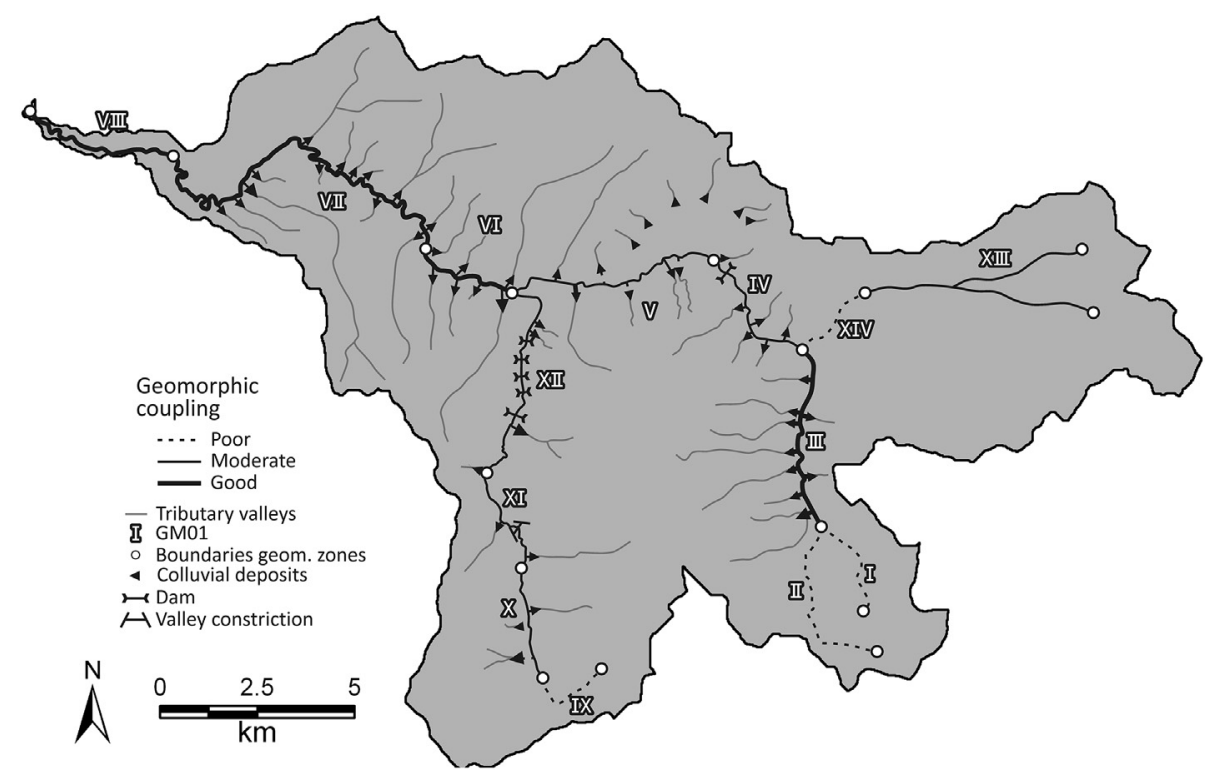

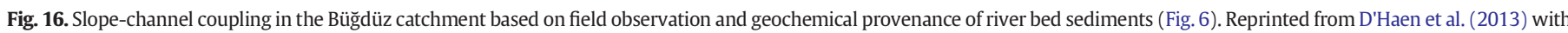
permission from Elsevier. 
age (Fig. 7). Here, punctuated input of sediment can keep pace with the incision driven by tectonic uplift. Further downstream, however, the incision rate is higher and the delivery of sediment more efficient thus generating several river terraces. In contrast, in the smaller intramontane basins in the headwaters of the catchment, sedimentation was mainly concentrated in the first major human impact 1000 $500 \mathrm{BC}$ and reworking of previously deposited sediment was not possible due to low stream gradients (Figs. $3 \mathrm{C}$ and 8). Neotectonics play an important role for many Mediterranean catchments. For instance, in the tectonically active setting of southeastern Spain, many studies have highlighted how active tectonics have influenced the pattern of anthropogenic sedimentation (e.g. Schulte, 2002; Bellin et al., 2013). For the Aguas River system in southeastern Spain, up to five Holocene river terraces can be found whereby cut-and-fill cycles are controlled by a large extent to the interaction between ongoing uplift (driving cut processes) and anthropogenic sedimentation (leading to a fill) (Schulte, 2002). Similar findings were reported for the Valdaine region in southern France (Notebaert et al., 2014).

For Mediterranean environments climate sensitivity also plays an important role. The pioneering work of Claudio Vita Finzi stressed the importance of climate in explaining the historical alluviation record for Mediterranean valleys (Vita-Finzi, 1969). This hypothesis has been debated by subsequent studies in Greece pointing to the importance of human pressure on the landscape (van Andel et al., 1986). Although many local studies indeed point out that sedimentation phases in the Late Holocene are poorly correlated to climate signals, the role of climate cannot be neglected for several periods of increased geomorphic activity, especially when regional scales are considered (Faust et al., 2004; Bellin et al., 2013). For arid to semi-arid regions like southeastern Spain or Tunisia, geomorphic instability is often correlated to drier periods that further degrade the vegetation cover making the landscape more vulnerable to the increasing frequency of torrential rain events that often accompany a dry period. Such landscapes are also less resilient to human pressure and thus human activity may intensify the climatic signal. In other regions, the return to moist conditions triggers more intense erosion, which again may be amplified through human activity. As Bellin et al. (2013; p. 124) pointed out: "improved hydrological conditions are associated with both reduced geomorphic stability and accelerated geomorphic instability dependent on the human impact on the environment. Periods of human occupation are not all directly associated with human accelerated sediment dynamics". Also for the Eastern Mediterranean, it has become clear that increased alluviation cannot be univoqually related to human impact or climate, but often to an interplay between both controlling factors (Bintliff, 2002; Fuchs, 2007; Casana, 2008).

For the Dijle catchment, and most likely also for other northwestern and central European regions, climate plays a much less important role. Model simulations show that anthropogenic land-cover change in the Dijle catchment since $5000 \mathrm{BP}$ is responsible for a 35 -fold increase in hillslope sediment delivery, whereas climate change only resulted in a $9 \%$ increase (Notebaert et al., 2011c). The lower climate sensitivity for the Dijle catchment is also due to the modest rainfall erosivities in this temperate climate. The mean RUSLE R-factor rainfall erosivity for central Belgium equals $871 \mathrm{MJ} \mathrm{mm} \mathrm{ha}{ }^{-1} \mathrm{~h}^{-1} \mathrm{a}^{-1}$, but values for individual years in the 20th century varied between 232 and $1540 \mathrm{MJ} \mathrm{mm} \mathrm{ha}{ }^{-1} \mathrm{~h}^{-1} \mathrm{a}^{-1}$ (Verstraeten et al., 2006). Rainfall erosivity in the eastern half of the USA, however, is much higher with average annual values ranging from approximately $1700 \mathrm{MJ} \mathrm{mm} \mathrm{ha} \mathrm{m}^{-1} \mathrm{~h}^{-1} \mathrm{a}^{-1}$ in northern Wisconsin up to $10,000 \mathrm{MJ} \mathrm{mm} \mathrm{ha} \mathrm{m}^{-1} \mathrm{~h}^{-1} \mathrm{a}^{-1}$ in the Gulf Coastal Plains (Renard et al., 1997). Clearing the land in such an erosive climate thus results in much higher erosion rates compared to northwestern Europe. The combination of this erosive climate with a more rapid agricultural expansion in the USA compared to northwestern European catchments characterized by a more gradual agricultural transition and a less erosive climate, explains the dramatic erosion rates and landscape ruination typical for many areas in the southern Piedmont
(Trimble, 1974), Mississippi (Happ et al., 1940) or the Upper Midwest (Trimble, 2013).

Landscape sensitivity does not only depend on the geomorphic setting, or changes in climate and soil systems, but it also depends strongly on the nature of the human impact itself. For the Dijle catchment, a threshold level in human pressure had to be crossed in the Medieval Period before delivery to the floodplain increased significantly. The increased levels of sedimentation in the last 1000 year, however, cannot be explained by the total area under cultivation alone, but also by changes in land and water management. Changes in hydro-sedimentary connectivity have been discussed in detail by Houben et al. (2013) for the Wetterau loess basin in Germany, and many of their findings are equally valid for the Dijle catchment. First of all, a major change in agricultural systems took place in the High Middle Ages with the implementation of the three-crop rotation system that minimised fallow periods. Second, this period also saw the development of large-scale hydraulic engineering practices such as water mills with either ponds or feeder channels as well as canalisation and stabilisation of river channels. Many wetland environments, including floodplains, were also reclaimed for agricultural practices. Large hydraulic works and intensification of land use in marginal areas were to a large extent initiated and managed by abbeys (Joris, 2006). Within the Dijle catchment, $>150$ watermills have been in operation (or still are), 44 of which were active before $1500 \mathrm{AD}$ (unpublished data). Many of the known watermills in the Dijle catchment were located directly on the river channel or on a parallel canal, and no milldams damming the entire floodplain are observed, except for the smaller tributaries. This is in contrast to the many milldams in the eastern USA that have controlled valley sedimentation to a large extent (Walter and Merritts, 2008). Through the technological developments in the Dijle catchment, it can be argued, therefore, that the fluvial system became more sensitive to higher rates of hillslope sediment delivery, but that floodplain geoecology changed as the indirect result of an intensification of agricultural activities. A thorough investigation on the medieval mills should unravel their specific role on changing floodplain morphology.

\section{Comparison to other conceptual models}

The discussion on the geomorphic response within each of the three case studies considered, also sheds light on the validity of the different conceptual models referred to in the introduction. Data from the Dijle and Büğdüz catchments suggests that (dis)connectivity, as eloquently and extensively defined by Fryirs (2013), plays an important role in explaining the delivery of sediment mobilised through human impact. For the Dijle catchment, lateral (dis)connectivity such as slope-channel coupling (Fig. 15) is critical to explain floodplain sedimentation rates and time lags between colluvial and alluvial sediment dynamics (Fig. 3A and B). However, the crossing of a threshold level in agricultural intensity does not simply represent switching on or off the connectivity between slopes and channels. The multi-temporal sediment budget (Fig. 2) indeed shows that the hillslope sediment delivery ratio (HSDR), equal to (sediment yield + floodplain storage) / production, before significant human impact (9000-2000 BC) was in fact higher $(\mathrm{HSDR}=95 \%)$ than during the periods of moderate impact (2000 BC$1000 \mathrm{AD})(\mathrm{HSDR}=45 \%$ ) and intense human impact (1000 AD-present) (HSDR $=62 \%$ ). Thus, although potential lateral connectivity between slopes and channels was reduced by natural forest cover in the Early to Mid-Holocene compared to Medieval and contemporary agricultural landscapes, more of the mobilised sediment reached the river channel in relative terms. We attribute this to the lower absolute amounts of mobilised sediment under forested conditions resulting in sediment transport rates on hillslopes well below the transport capacity of overland flow. When the land is cleared, erosion rates are much higher and sediment transport capacity is exceeded, resulting in colluviation and hence lower HSDR-values (see also Verstraeten et al., 2009; Notebaert et al., 2011c). Furthermore, the time-transgressive nature of 
the changes in floodplain geoecology between tributaries and the main trunk valley (Fig. 4B and C) cannot be explained only by temporal differences in (dis)connectivity but rather by differences in response time in relation to the size of the floodplain. Thus, the (dis)connectivity model is very useful to explain part of the human-impacted sediment dynamics in the Dijle catchment, but definitely not all the observed geomorphic changes. For the Büğdüz catchment, longitudinal (dis)connectivity controlled by the tectonic setting (Figs. 6 and 16) is more important. However, the (dis)connectivity model fails to explain the lower rates of sedimentation in the Büğdüz catchment during the periods of most intense human impact. Indeed, during the BOP, connectivity between slopes and channels, as well as within channel systems, did not significantly change compared to the preceding Iron Age. The soil erosion-soil thickness feedback system (Fig. 9) overrode the importance of connectivity.

The analysis of the geomorphic response in all three case studies also shows that the sediment cascade and reservoir system in its simplest form (Lang and Hönscheidt, 1999; Zolitschka et al., 2003; Hoffmann, 2015), i.e., sediment moves or cascades from one sediment sink to the next one, cannot be confirmed by the data. For the Dijle catchment, floodplain sedimentation and fluvial sediment export is already important before colluvial sediment sinks are full. In fact, colluvial sedimentation is still continuing under present-day agricultural conditions and has remained a net sediment trap during periods with high floodplain aggradation rates. Detailed analysis of major colluvial sinks does show that these sinks occasionally turned into sediment sources through gullying but their net effect has been rather limited (Rommens et al., 2007). Furthermore, hillslope SDR-values calculated using the sediment budget approach (62\% since $1000 \mathrm{AD}$; see above) are in correspondence to hillslope SDR-values for various individual rain and runoff events (Steegen et al., 2000; van Oost et al., 2005) suggesting that the longer timescale at which colluvial storage is considered does not introduce a bias. The central part of the Büğdüz floodplain between Büğdüz and Bayinder switches between a sediment source and sink several times (Fig. 7), whilst various sinks farther upstream in the basin near Bereket and Beşkavak continued to act as a sink, albeit at lower rates (Fig. 8). Only for the USA, can a downstream shift in loci of maximum alluvial sediment deposition be observed, which is interpreted as the downstream movement of a sediment pulse. However, floodplains in the upper valley of Coon Creek, for instance, did not shift to a sediment source because this sink was near its maximum storage capacity, but rather because much less new material was delivered from the adjoining hillslopes. The fact that the USA catchments most closely represent the sediment cascade model is thus rather due to the relative short duration of the disturbance event that released large quantities of sediment in the late 19th-early 20th century. Under conditions of sustained, and even continuously increasing human impact like in the Belgian Loess landscapes, a true cascading effect is not discernable.

Trimble (2010) introduced the 'fast-in, slow-out' model from his observations in Coon Creek, and also noticed synergies with the response of alluvial systems in other regions, including catchments in northwestern Europe. The model assumes that the rate of floodplain aggradation is higher than the rate at which this material is being reworked by lateral processes. This assumption is seemingly valid for Coon Creek and other catchments in the New World that were confronted with relatively short but intense events. Unfortunately, whilst rates of aggradation are available for many depositional sites in both the Dijle and Büğdüz catchments, very little is known about rates of lateral fluvial activity at longer timescales. Nevertheless, some observations indeed point to the validity of the model. The sedimentation curves for the Büğdüz catchment (Fig. 8), for instance, do show that $20-50 \%$ of the total sediment storage in the upstream valley systems was deposited within a few centuries, whilst the median sediment age varies between 1500 and 3000 year. The fact that the major sediment crisis took place during the Iron Age and that since then, many sediment sinks remained intact, indeed shows that 'fast-in, slow-out' is definitely valid. On the other hand, for the lower valleys (Fig. 7), the various cut-and-fill cycles show that both periods as well as volumes of aggradation and incision may balance each other, suggesting that at least for these floodplain locations, 'fast-in, fast-out' would be a more appropriate description. For the Dijle catchment, the median age of anthropogenic floodplain sediment equals approximately 1000 year (van Oost et al., 2012), but this value is not higher than the duration of human impact or the time needed to aggrade the floodplain. Furthermore, sediment input into the fluvial system took several thousand years, which may be considered 'fast' at geologic timescales but not at the scale at which human impact on geomorphic systems is considered. As long as human impact continues to be important in the Dijle catchment, additional sediment may be brought into the fluvial system. It remains unresolved so far how rates of reworking would evolve when sediment delivery would be strongly diminished. It can be hypothesised that a reduced sediment input in the Dijle catchment would result in the development of an inset floodplain, similar to what has been observed in Coon Creek (Trimble, 2010). In that case, the removal rate will be much lower. If, however, the Dijle floodplain would follow the same trajectory as the lower alluvial valleys in the Büğdüz, the mean residence time may become much shorter. The 'fast-in, slow-out' model thus also seems to be largely dependent on the specific geomorphic conditions and the duration of human disturbance. More data on sediment residence time for a wider range of settings is needed to further test the validity of the "fast-in, slow-out' model.

Thus, no single model can explain the observed complexity and variability in geomorphic response following anthropogenic disturbance for the three case studies considered. Although these three case studies are unique, the similarity in geomorphic evolution and responses to many other catchments in their respective environmental settings (see discussion in sections 3.1 to 3.4), suggests that the validity of all generalised models of sediment transfers can be questioned. In fact, all these conceptual models, i.e., the sediment cascade model, the (dis)connectivity model, and the 'fast-in, slow-out' model, are defined very broadly with the aim to be applicable to a wide range of systems. The fact that even such broadly defined concepts are not always applicable, although they can be valid for particular periods or regions as we have illustrated above, suggests that it may be useful instead to develop a new array of conceptual models such as those presented in Fig. 14 for the contrasting three case studies. Such models emphasize the trajectory of geomorphic response to anthropogenic disturbance. These models showcase under which conditions of geomorphic setting and characteristics of anthropogenic activities, differences in fluvial system response can be expected. Such trajectory models can be further developed, extended to other settings, and validated with many more case studies.

\section{Legacy landforms}

Over the last decade, floodplain sediments resulting from accelerated anthropogenic erosion have often been described as legacy sediment (e.g. James, 2013). However, legacy sediment is only one aspect of the historic legacy of anthropogenic disturbance. The variability in geomorphic response to anthropogenic disturbance has indeed resulted in a variety of specific landforms that equally can be considered as legacy landscapes.

The above discussion for the Dijle catchment shows that the fluvial system transformed from a natural status with wetlands and absence of major channels towards a floodplain with a single-thread meandering channel and thick mineral sediment deposits. The present-day landscape is thus an anthropogenic fluvial or legacy landscape. Similar findings have been made for meandering rivers in the eastern US where increased sedimentation behind mill dams led to the formation of single-thread meandering channels from marshy multi-channel morphologies (Walter and Merritts, 2008), raising questions of how natural contemporary rivers really are (Montgomery, 2008). Although the 
increase in cohesive sediment input into the fluvial system is similar for both settings, both intensity and typology of human disturbance is different. Indeed, whereas mill dams were needed to retain the anthropogenic sediment in the fluvial system in the eastern US over a period of two centuries, the large cumulative addition of fine sediment over a time period of several centuries to millennia created similar landforms in the European loess regions. Lewin $(2010,2013)$ discusses the transformation of many floodplains in the UK and points to the combination of changes in sediment delivery and local technological interventions (embankments, bridges, straightening of channels, etc.) when explaining the disappearance of anastomosing rivers and wetland environments.

The legacy of century- to millennia-long anthropogenic accelerated erosion also led to soil profile truncation and infilling of dry valleys. As a result, hillslope topography has smoothened (Rommens et al., 2005; Rommens et al., 2007). Although gully erosion can be held responsible for up to $40-50 \%$ of total erosion in the Belgian Loess Belt (e.g. Poesen et al., 2003), the often meter-deep gullies that temporarily form on agricultural land following low frequency-high intensity rain events (e.g. Vanwalleghem et al., 2003) normally have a lifespan of only 1025 year. Consequent soil erosion during high to medium frequency events on nearby cultivated slopes delivers sediment to the gullies that fill up again (e.g. Vanwalleghem et al., 2005a). Only at a few locations where forest has regrown on intensely gullied landscapes, are these erosional features still preserved in the landscape (Vanwalleghem et al., 2003; Vanwalleghem et al., 2005b). Gullies under forest are a typical legacy landform not only in the central Belgian Loess Belt but similar examples can be found throughout central Europe (Stankoviansky, 2003; Dotterweich, 2005; Larsen et al., 2013) and also in many formerly cultivated areas in the US (e.g. James et al., 2007; Sutter, 2010; Sutter, 2015).

The present-day Mediterranean mountain landscape in southwestern Turkey is dominated by steep slopes with minimal soil thickness and mostly rocky outcrops whereas intramontane basins and floodplains are characterized by thick soils being the result of the deposition of eroded material. This patchy landscape can thus partly be seen as a legacy of (pre)historic erosion and aggradation. It is typical for many Mediterranean regions such as the Argolid in Greece (van Andel et al., 1986) or the Drama plains in Macedonia (Lespez, 2003).

\section{Implications for unravelling the human impact on fluvial systems}

Human impacts on fluvial systems are often quantified through the analysis of sediment yield data for catchments with contrasting intensities of anthropogenic land use (Syvitski and Milliman, 2007; Vanmaercke et al., 2015). Changes in sediment yield for a given catchment are likewise often considered as an indication of changes in human (or climate) impact (Walling and Fang, 2003; Wang et al., 2007). Other studies quantify human impact by comparing modern sediment yield data with long-term geologic rates or erosion using cosmogenic nuclides (e.g. Gellis et al., 2004; Vanacker et al., 2007). The use of sediment archives has become one of the main methods to unravel past human impact on the environment, especially in the absence of longterm sediment yield records (e.g. Lang et al., 2003a; Macklin et al., 2005; Foulds and Macklin, 2006; James and Marcus, 2006; Hoffmann et al., 2009; Notebaert and Verstraeten, 2010; Dusar et al., 2011; Bellin et al., 2013; Dotterweich, 2013; James, 2013; Jones et al., 2015).

However, the various factors controlling the delivery of sediment towards and within the fluvial system complicate the reconstruction of the driving factors including human pressure. As discussed above, slope-channel coupling, feedbacks in the soil system, the geomorphic setting and the interaction with changing climate may all vary between catchments making every catchment unique with respect to its sensitivity to human pressure (Figs. 13 and 14). Furthermore, this sensitivity not only varies spatially between catchments, it also varies through time. When considering the Dijle, Büğgüz and Coon Creek catchments, which sediment archive should be studied to unravel the human history? For which sediment archive does the rate of aggradation correspond to the intensity of human pressure on the landscape in general, and the fluvial system in particular? It is clear from all these cases that there is no straightforward answer. When focusing on the main trunk of the Dijle floodplain, one misses the early human impact that is only seen in colluvial deposits (Figs. 3 and 14). Furthermore, spatial patterns of human pressure may be missed as some tributary systems respond earlier than others (Fig. 4). Likewise for the Büğdüz catchment, focusing only on the downstream depositional centers will largely underestimate the early human impact that is mainly to be found in the upstream depositional basins (Fig. 3C-E). For Coon Creek, rates of sediment export do not vary significantly over the period 1853-1993 although human pressure and erosion does (Trimble, 1999). Upstream tributaries in Coon Creek show their highest sedimentation rate early in the 20th century, whilst the peak sedimentation rate in the lower main valley arrives 20-30 year later (Fig. 11; Trimble, 2008; Trimble, 2013) and the Upper Mississippi Valley to which Coon Creek drains is still experiencing elevated sedimentation rates (Fig. 12; Belmont et al., 2011).

The various factors controlling the propagation or damping of human signals in fluvial systems discussed above for the three contrasting environments have been illustrated for many other systems as well. Changing levels of (dis)connectivity through time and the impact on sediment delivery have been illustrated before for a wide range of environments (e.g. Harvey, 2002; Fryirs et al., 2007; Fuchs et al., 2010; Houben et al., 2013). There is a growing consensus that most biophysical systems are complex in nature and are characterized by non-linear impact-response relations, tipping points and internal feedback mechanisms (e.g. Phillips, 2006; Murray et al., 2009). This certainly holds for coupled socio-ecological systems (e.g. Widlok et al., 2012) and it has even been argued that the non-linearity becomes even more important when the system is under significant anthropogenic pressure (Knight and Harrison, 2014).

Resolving the complexity problem requires a deeper understanding of the various mechanisms operating in the (dis)connected hillslopefluvial system (Fryirs, 2013). This requires not only the identification of the various sources and sinks within a hillslope-fluvial system, as well as the pathways connecting sources and sinks. Equally important is that all these storage components and fluxes are quantified (Verstraeten, 2014), for instance through the construction of sediment budgets. Sediment budgets also allow calculation of sediment delivery ratios, and thus assess how much of the anthropogenic sediment is still buffered within the slope and fluvial systems (Slaymaker, 2003). Many historic sediment budgets show that more than half and even up to $90 \%$ of the anthropogenic erosion material is still situated within the catchment, either as colluvium or alluvium (Beach, 1994; Trimble, 1999; Fryirs and Brierley, 2001; Verstraeten et al., 2009; Notebaert et al., 2011b; Houben, 2012). The construction of sufficiently detailed sediment budgets requires a catchment-wide approach whereby much data is required on variability in sediment thickness (Notebaert et al., 2010). Separate quantification of floodplain storage in tributary systems, and the up- and downstream main valley in Coon Creek enables a look at spatial variability in catchment response, which is not possible at a lower spatial resolution (Trimble, 1999). In many cases, total sediment budgets are constructed for a single time period (e.g. Dietrich and Dunne, 1978; Beach, 1994). Time-differentiated sediment budgets are still limited to a few catchments (including the Dijle and Coon Creek catchments), yet do offer much more potential as it is possible to look at changes in the relative importance of the various budget components (see Fig. 2 and discussion in section 3.3). Changes in sediment delivery ratios between historic time periods can be derived from time-differentiated sediment budgets pointing to changes in, for instance, slope-channel coupling (Verstraeten et al., 2009). However, this requires not only a high spatial resolution but also a sufficiently high temporal resolution of the sedimentary record, which is often lacking. Sediment fingerprinting may complement quantitative estimates of 
sinks and sources (Collins et al., 1997; D'Haen et al., 2012), as is shown here for the Büğgüz catchment (Fig. 6) or for the US (Fig. 12B), as it provides additional information on how sinks and sources are spatially connected. Fingerprinting can be considered a means to enlighten the gray box that a sediment budget represents. As discussed above (section 4), legacy landforms may hold another key when unravelling the human impact on soil and fluvial landscapes, and in fact, should be used as complementary information to quantitative estimates of sediment sinks and sources. More than quantitative sediment budgets, legacy landforms may point to important tipping points in the relation between human pressure and geomorphic response.

What is often forgotten, or badly represented, in many geomorphic human impact studies, is an accurate reconstruction of the intensity and typology of human disturbance. For historic periods, such as the Euro-American agricultural expansion in 19th century USA, a wealth of historic documents is available (Trimble, 1974; Trimble, 2013). However, for understanding the human-environment interactions in the more distant past, e.g., in Europe and the Mediterranean, such information is much more limited. Local archaeological data is often fragmented and potentially biased as well, often leading only to qualitative statements about correlations with the sedimentary record. Global historic land-cover reconstructions (e.g. Kaplan et al., 2011) do reveal broadscale patterns and evolutions in anthropogenic land cover, yet their resolution and accuracy for specific catchments is often too low to make direct comparisons with the fluvial record (De Brue and Verstraeten, 2014). Pollen-based quantitative estimates of human impact (e.g., Fig. 4A) that are analyzed for the same region as for which the fluvial record is being studied may provide an alternative (Broothaerts et al., 2014c; Broothaerts et al., 2014b).

\section{Acknowledgments}

This research is funded by the Interuniversitary Attractions Pole programs IAP 06/22 and 7/09, initiated by the Belgian Science Policy Office, the Fund for Scientific Research, Flanders (research project G.0583.06), and the Concerted Action of the Flemish Government (GOA/2007/02). The authors would like to thank the many Geography students that participated with field work in the Dijle catchment and in the geomorphic surveys within the Sagalassos archaeological research project. We also would like to thank three anonymous reviewers and the editors of this special issue, Allan James and Scott Lecce, for their critical and encouraging comments on an earlier draft of this manuscript.

\section{Appendix A. Supplementary data}

Supplementary data associated with this article can be found in the online version, at http://dx.doi.org/10.1016/j.geomorph.2017.03.027. These data include the Google maps of the most important areas described in this article.

\section{References}

Bakker, J., Kaniewski, D., Verstraeten, G., de Laet, V., Waelkens, M., 2011. Numerically derived evidence for late-Holocene climate change and its impact on human presence in the southwest Taurus Mountains, Turkey. The Holocene 22 (4), 425-438.

Bakker, J., Paulissen, E., Kaniewski, D., de Laet, V., Verstraeten, G., Waelkens, M., 2012. Man, vegetation and climate during the Holocene in the territory of Sagalassos, Western Taurus Mountains, SW Turkey. Veg. Hist. Archaeobotany 21 (4-5), 249-266.

Beach, T., 1994. The fate of eroded soil: sediment sinks and sediment budgets of agrarian landscapes in southern Minnesota, 1851-1988. Ann. Assoc. Am. Geogr. 84 (1), 5-28.

Bellin, N., Vanacker, V., de Baets, S., 2013. Anthropogenic and climatic impact on Holocene sediment dynamics in SE Spain: a review. Quat. Int. 308, 112-129.

Belmont, P., Gran, K.B., Schottler, S.P., Wilcock, P.R., Day, S.S., Jennings, C., Lauer, J.W. Viparelli, E., Willenbring, J.K., Engstrom, D.R., 2011. Large shift in source of fine sediment in the Upper Mississippi River. Environ. Sci. Technol. 45 (20), 8804-8810.

Bennett, H.H., 1928. Soil Erosion a National Menace.

Bennett, H.H., 1939. Soil Conservation. McGraw-Hill Book Company, New York and London.

Bennett, H.H., 1944. Thomas Jefferson, Soil Conservationist. US Dept. of Agriculture, Soil Conservation Service.
Bintliff, J., 2002. Time, process and catastrophism in the study of Mediterranean alluvial history: a review. World Archaeol. 33 (3), 417-435.

Blum, M.D., Törnqvist, T.E., 2000. Fluvial responses to climate and sea-level change: a review and look forward. Sedimentology 47 (s1), 2-48.

Broothaerts, N., Notebaert, B., Verstraeten, G., Kasse, C., Bohncke, S., Vandenberghe, J., 2014a. Non-uniform and diachronous Holocene floodplain evolution: a case study from the Dijle catchment, Belgium. J. Quat. Sci. 29 (4), 351-360.

Broothaerts, N., Verstraeten, G., Kasse, C., Bohncke, S., Notebaert, B., Vandenberghe, J., 2014b. From natural to human-dominated floodplain geoecology - a Holocene perspective for the Dijle catchment. Anthropocene 8, 46-58.

Broothaerts, N., Verstraeten, G., Kasse, C., Bohncke, S., Notebaert, B., Vandenberghe, J. 2014c. Reconstruction and semi-quantification of human impact in the Dijle catchment, central Belgium: a palynological and statistical approach. Quat. Sci. Rev. 102, 96-110.

Burt, T., Allison, R.J., 2010. Sediment Cascades: An Integrated Approach. John Wiley \& Sons.

Casana, J., 2008. Mediterranean valleys revisited: linking soil erosion, land use and climate variability in the Northern Levant. Geomorphology 101 (3), 429-442.

Chiverrell, R.C., Thorndycraft, V.R., Hoffmann, T.O., 2011. Cumulative probability functions and their role in evaluating the chronology of geomorphological events during the Holocene. J. Quat. Sci. 26 (1), 76-85.

Church, M., Slaymaker, O., 1989. Disequilibrium of Holocene sediment yield in glaciated British Columbia. Nature 337 (6206), 452-454

Collins, A., Walling, D., Leeks, G., 1997. Use of the geochemical record preserved in floodplain deposits to reconstruct recent changes in river basin sediment sources. Geomorphology 19 (1-2), 151-167.

Crombé, P., Vanmontfort, B., Whittle, A., Cummings, V., 2007. The neolithisation of the Scheldt basin in western Belgium. Going Over: The Mesolithic-Neolithic Transition in North-west Europe. Proceedings of the British Academy Press, pp. 263-285.

de Bow, J.D.B., 1853. The Industrial Resources, Etc., of the Southern and Western States: Embracing a View of Their Commerce, Agriculture, Manufactures, Internal Improvements, Slave and Free Labor, Slavery Institutions, Products, Etc., of the South: Together with Historical and Statistical Sketches of the Different States and Cities of the Union: Statistics of the United States Commerce and Manufactures, from the Earliest Periods, Compared with Other Leading Powers: the Results of the Different Census Returns Since 1790, and Returns of the Census of 1850, on Population, Agriculture and General Industry, Etc.: with an Appendix, 2. Office of De Bow's review.

de Brue, H., 2016. Modelling long-term anthropogenic land cover change and environmental impact in the central Belgian Loess Belt. Integration of Archaeological, Geomorphological and Palynological Records, Leuven. Department of Earth and Environmental Sciences, KU Leuven (PhD thesis).

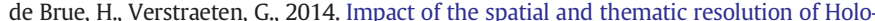
cene anthropogenic land-cover scenarios on modeled soil erosion and sediment delivery rates. The Holocene 24 (1), 67-77.

de Cupere, B., Frémondeau, D., Kaptijn, E., Marinova, E., Poblome, J., Vandam, R., van Neer W., 2015. Subsistence economy and land use strategies in the Burdur province (SW Anatolia) from prehistory to the Byzantine period. Quat. Int.

de Moor, J.J.W., Kasse, C., van Balen, R., Vandenberghe, J., Wallinga, J., 2008. Human and climate impact on catchment development during the Holocene - Geul River, the Netherlands. Geomorphology 98 (3-4), 316-339.

de Vente, J., Poesen, J., Arabkhedri, M., Verstraeten, G., 2007. The sediment delivery problem revisited. Prog. Phys. Geogr. 31 (2), 155-178.

Dearing, J.A., Jones, R.T., 2003. Coupling temporal and spatial dimensions of global sediment flux through lake and marine sediment records. Glob. Planet. Chang. 39 (1) 147-168.

Dearing, J., Battarbee, R., Dikau, R., Larocque, I., Oldfield, F., 2006. Human-environment interactions: learning from the past. Reg. Environ. Chang. 6 (1-2), 1-16.

Delcourt, P.A., Delcourt, H.R., 2004. Prehistoric Native Americans and ecological change. Human Ecosystems in Eastern North America since the Pleistocene. Cambridge University Press.

D'Haen, K., 2012. Fingerprinting Late Holocene Sediment Fluxes in an Eastern Mediterranean Mountain Catchment, Leuven. Department of Earth and Environmental Sciences, KU Leuven ( $\mathrm{PhD}$ thesis).

D'Haen, K., Verstraeten, G., Degryse, P., 2012. Fingerprinting historical fluvial sediment fluxes. Prog. Phys. Geogr. 36 (2), 154-186.

D'Haen, K., Dusar, B., Verstraeten, G., Degryse, P., de Brue, H., 2013. A sediment fingerprinting approach to understand the geomorphic coupling in an eastern Mediterranean mountainous river catchment. Geomorphology 197, 64-75.

Dietrich, W., Dunne, T., 1978. Sediment Budget for a Small Catchment in a Mountainous Terrain.

Dijk, W.M., Lageweg, W.I., Kleinhans, M.G., 2013. Formation of a cohesive floodplain in a dynamic experimental meandering river. Earth Surf. Process. Landf. 38 (13), 1550-1565.

Dotterweich, M., 2005. High-resolution reconstruction of a 1300 year old gully system in northern Bavaria, Germany: a basis for modelling long-term human-induced landscape evolution. The Holocene 15 (7), 994-1005.

Dotterweich, M. 2008. The history of soil erosion and fluvial deposits in small catchments of central Europe: deciphering the long-term interaction between humans and the environment - a review. Geomorphology 101 (1-2), 192-208.

Dotterweich, M., 2013. The history of human-induced soil erosion: geomorphic legacies, early descriptions and research, and the development of soil conservation-a global synopsis. Geomorphology 201, 1-34.

Dotterweich, M., Ivester, A.H., Hanson, P.R., Larsen, D., Dye, D.H., 2014. Natural and human-induced prehistoric and historical soil erosion and landscape development in Southwestern Tennessee, USA. Anthropocene 8, 6-24. 
Dusar, B., 2011. Late Holocene Sediment Dynamics in a Mediterranean Mountain Environment, Leuven. Department of Earth and Environmental Sciences, KU Leuven (PhD thesis).

Dusar, B., Verstraeten, G., Notebaert, B., Bakker, J., 2011. Holocene environmental change and its impact on sediment dynamics in the Eastern Mediterranean. Earth Sci. Rev. 108 (3-4), 137-157.

Dusar, B., Verstraeten, G., D'Haen, K., Bakker, J., Kaptijn, E., Waelkens, M., 2012. Sensitivity of the Eastern Mediterranean geomorphic system towards environmental change during the Late Holocene: a chronological perspective. J. Quat. Sci. 27 (4), 371-382.

Ellis, E.C., Kaplan, J.O., Fuller, D.Q., Vavrus, S., Goldewijk, K.K., Verburg, P.H., 2013. Used planet: a global history. Proc. Natl. Acad. Sci. 110 (20), 7978-7985.

Faust, D., Zielhofer, C., Escudero, R.B., del Olmo, F.D., 2004. High-resolution fluvial record of late Holocene geomorphic change in northern Tunisia: climatic or human impact? Quat. Sci. Rev. 23 (16), 1757-1775.

Foulds, S.A., Macklin, M.G., 2006. Holocene land-use change and its impact on river basin dynamics in Great Britain and Ireland. Prog. Phys. Geogr. 30 (5), 589-604.

Fryirs, K., 2013. (Dis)Connectivity in catchment sediment cascades: a fresh look at the sediment delivery problem. Earth Surf. Process. Landf. 38 (1), 30-46.

Fryirs, K., Brierley, G.J., 2001. Variability in sediment delivery and storage along river courses in Bega catchment, NSW, Australia: implications for geomorphic river recovery. Geomorphology 38 (3), 237-265.

Fryirs, K.A., Brierley, G.J., Preston, N.J., Kasai, M., 2007. Buffers, barriers and blankets: the (dis) connectivity of catchment-scale sediment cascades. Catena 70 (1), 49-67.

Fuchs, M., 2007. An assessment of human versus climatic impacts on Holocene soil erosion in NE Peloponnese, Greece. Quat. Res. 67 (3), 349-356.

Fuchs, M., Fischer, M., Reverman, R., 2010. Colluvial and alluvial sediment archives temporally resolved by OSL dating: implications for reconstructing soil erosion. Quat. Geochronol. 5 (2), 269-273.

Gellis, A.C., Pavich, M.J., Bierman, P.R., Clapp, E.M., Ellevein, A., Aby, S., 2004. Modern sediment yield compared to geologic rates of sediment production in a semi-arid basin, New Mexico: assessing the human impact. Earth Surf. Process. Landf. 29 (11) $1359-1372$.

Hall, A.R., 1937. Early Erosion-Control Practices in Virginia. US Dept. of Agriculture.

Happ, S.C., 1944. Effect of sedimentation on floods in the Kickapoo Valley, Wisconsin. J. Geol. 53-68.

Happ, S.C., 1945. Sedimentation in South Carolina piedmont valleys. Am. J. Sci. 243 (3), 113-126.

Happ, S.C., Rittenhouse, G., Dobson, G.C., 1940. Some Principles of Accelerated Stream and Valley Sedimentation. US Department of Agriculture.

Harvey, A.M., 2002. Effective timescales of coupling within fluvial systems. Geomorphology 44 (3), 175-201.

Hoffmann, T., 2015. Sediment residence time and connectivity in non-equilibrium and transient geomorphic systems. Earth Sci. Rev. 150, 609-627.

Hoffmann, T., Erkens, G., Gerlach, R., Klostermann, J., Lang, A., 2009. Trends and controls of Holocene floodplain sedimentation in the Rhine catchment. Catena 77 (2), 96-106.

Houben, P., 2012. Sediment budget for five millennia of tillage in the Rockenberg catchment (Wetterau loess basin, Germany). Quat. Sci. Rev. 52, 12-23.

Houben, P., Schmidt, M., Mauz, B., Stobbe, A., Lang, A., 2013. Asynchronous Holocene colluvial and alluvial aggradation: a matter of hydrosedimentary connectivity. The Holocene 23 (4), 544-555.

James, L.A., 2011. Contrasting geomorphic impacts of pre-and post-Columbian land-use changes in Anglo America. Phys. Geogr. 32 (5), 399-422.

James, L.A., 2013. Legacy sediment: definitions and processes of episodically produced anthropogenic sediment. Anthropocene 2, 16-26.

James, L.A., Marcus, W.A., 2006. The human role in changing fluvial systems: retrospect, inventory and prospect. Geomorphology 79 (3), 152-171

James, L.A., Watson, D.G., Hansen, W.F., 2007. Using LiDAR data to map gullies and headwater streams under forest canopy: South Carolina, USA. Catena 71 (1), 132-144.

Jones, A.F., Macklin, M.G., Benito, G., 2015. Meta-analysis of Holocene fluvial sedimentary archives: a methodological primer. Catena 130, 3-12.

Joris, F. (Ed.), 2006. Les réseaux hydrauliques des abbayes cisterciennes du Nord de la France et de Wallonie. Institut du patrimoine Wallon.

Kaniewski, D., Paulissen, E., de Laet, V., Dossche, K., Waelkens, M., 2007. A high-resolution Late Holocene landscape ecological history inferred from an intramontane basin in the Western Taurus Mountains, Turkey. Quat. Sci. Rev. 26 (17-18), 2201-2218.

Kaplan, J.O., Krumhardt, K.M., Ellis, E.C., Ruddiman, W.F., Lemmen, C., Goldewijk, K.K. 2011. Holocene carbon emissions as a result of anthropogenic land cover change. The Holocene 21 (5), 775-791.

Knight, J., Harrison, S., 2014. Limitations of uniformitarianism in the Anthropocene Anthropocene 5, 71-75.

Knox, J.C., 1972. Valley alluviation in southwestern Wisconsin. Ann. Assoc. Am. Geogr. 62 (3), 401-410.

Knox, J.C., 1977. Human impact on Wisconsin stream channels. Annals of the Association of American Geographers. 67(3), pp. 323-342.

Knox, J.C., 1987. Historical valley floor sedimentation in the Upper Mississippi Valley. Ann. Assoc. Am. Geogr. 77 (2), 224-244.

Knox, J.C., 2006. Floodplain sedimentation in the Upper Mississippi Valley: natural versus human accelerated. Geomorphology 79 (3), 286-310.

Lang, A., Hönscheidt, S., 1999. Age and source of colluvial sediments at Vaihingen-Enz, Germany. Catena 38 (2), 89-107.

Lang, A., Bork, H.R., Mackel, R., Preston, N., Wunderlich, E., Dikau, R., 2003a. Changes in sediment flux and storage within a fluvial system: some examples from the Rhine catchment. Hydrol. Process. 17 (16), 3321-3334.

Lang, A., Niller, H.P., Rind, M.M., 2003b. Land degradation in Bronze Age Germany: archaeological, pedological, and chronometrical evidence from a hilltop settlement on the Frauenberg, Niederbayern. Geoarchaeology 18 (7), 757-778.
Larsen, A., Bork, H.-R., Fuelling A., Fuchs, M., Larsen, J.R., 2013. The processes and timing of sediment delivery from headwaters to the trunk stream of a Central European mountain gully catchment. Geomorphology 201, 215-226.

Leigh, D.S., Webb, P.A., 2006. Holocene erosion, sedimentation, and stratigraphy at Raven Fork, southern Blue Ridge Mountains, USA. Geomorphology 78 (1), 161-177.

Lespez, L., 2003. Geomorphic responses to long-term land use changes in Eastern Macedonia (Greece). Catena 51 (3), 181-208.

Lewin, J., 2010. Medieval environmental impacts and feedbacks: the lowland floodplains of England and Wales. Geoarchaeology 25 (3), 267-311.

Lewin, J., 2013. Enlightenment and the GM floodplain. Earth Surf. Process. Landf. 38 (1), $17-29$.

Lewin, J., Macklin, M.G., 2003. Preservation potential for Late Quaternary river alluvium. J. Quat. Sci. 18 (2), 107-120.

Lowdermilk, W., 1953. Conquest of the land through 7,000 years. USDA-SCS, Agr. Info. Bull. 99.

Lowe, E.N., 1910. Our Waste Lands: A Preliminary Study of Erosion in Mississippi. Brandon.

Macaire, J.J., Bellemlih, S., Di-Giovanni, C., de Luca, P., Visset, L., Bernard, J., 2002. Sediment yield and storage variations in the Négron River catchment (south western Parisian Basin, France) during the Holocene period. Earth Surf. Process. Landf. 27 (9), 991-1009.

Macklin, M.G., Johnstone, E., Lewin, J., 2005. Pervasive and long-term forcing of Holocene river instability and flooding in Great Britain by centennial-scale climate change. The Holocene 15 (7), 937-943.

Macklin, M.G., Jones, A.F., Lewin, J., 2010. River response to rapid Holocene environmental change: evidence and explanation in British catchments. Quat. Sci. Rev. 29 (13-14), 1555-1576.

Macklin, M.G., Jones, A.F., Lewin, J., 2011. Comment: cumulative probability functions and their role in evaluating the chronology of geomorphological events during the Holocene. J. Quat. Sci. 26 (2), 238-240.

Magilligan, F.J., 1985. Historical floodplain sedimentation in the Galena River basin, Wisconsin and Illinois. Ann. Assoc. Am. Geogr. 75 (4), 583-594.

Meade, R.H., 1982. Sources, sinks, and storage of river sediment in the Atlantic drainage of the United States. The Journal of Geology 235-252.

Meybeck, M., Vörösmarty, C., 2005. Fluvial filtering of land-to-ocean fluxes: from natural Holocene variations to Anthropocene. Compt. Rendus Geosci. 337 (1-2), 107-123.

Montgomery, D.R., 2007a. Dirt: The Erosion of Civilizations. Univ of California Press.

Montgomery, D.R., 2007b. Soil erosion and agricultural sustainability. Proc. Natl. Acad. Sci. 104 (33), 13268-13272.

Montgomery, D.R., 2008. Dreams of natural streams. Science 319 (5861), 291-292.

Murray, A.B., Lazarus, E., Ashton, A., Baas, A., Coco, G., Coulthard, T., Fonstad, M., Haff, P., McNamara, D., Paola, C., 2009. Geomorphology, complexity, and the emerging science of the Earth's surface. Geomorphology 103 (3), 496-505.

Notebaert, B., Verstraeten, G., 2010. Sensitivity of West and Central European river systems to environmental changes during the Holocene: a review. Earth Sci. Rev. 103 (3-4), 163-182.

Notebaert, B., Verstraeten, G., Rommens, T., Vanmontfort, B., Govers, G., Poesen, J., 2009. Establishing a Holocene sediment budget for the river Dijle. Catena 77 (2), 150-163.

Notebaert, B., Verstraeten, G., Govers, G., Poesen, J., 2010. Quantification of alluvial sediment storage in contrasting environments: methodology and error estimation. Catena $82(3), 169-182$

Notebaert, B., Houbrechts, G., Verstraeten, G., Broothaerts, N., Haeckx, J., Reynders, M., Govers, G., Petit, F., Poesen, J., 2011a. Fluvial architecture of Belgian river systems in contrasting environments: implications for reconstructing the sedimentation history. Netherlands Journal of Geosciences-Geologie En Mijnbouw 90 (1), 31-50.

Notebaert, B., Verstraeten, G., Vandenberghe, D., Marinova, E., Poesen, J., Govers, G., 2011b. Changing hillslope and fluvial Holocene sediment dynamics in a Belgian loess catchment. J. Quat. Sci. 26 (1), 44-58.

Notebaert, B., Verstraeten, G., Ward, P., Renssen, H., van Rompaey, A., 2011c. Modeling the sensitivity of sediment and water runoff dynamics to Holocene climate and land use changes at the catchment scale. Geomorphology 126 (1-2), 18-31.

Notebaert, B., Berger, J.-F., Brochier, J.L., 2014. Characterization and quantification of Holocene colluvial and alluvial sediments in the Valdaine Region (southern France). The Holocene 24 (10), 1320-1335.

Phillips, J., 2006. Evolutionary geomorphology: thresholds and nonlinearity in landform response to environmental change. Hydrol. Earth Syst. Sci. 10, 731-742.

Phillips, J.D., Marden, M., Gomez, B., 2007. Residence time of alluvium in an aggrading fluvial system. Earth Surf. Process. Landf. 32 (2), 307-316.

Poesen, J., Nachtergaele, J., Verstraeten, G., Valentin, C., 2003. Gully erosion and environmental change: importance and research needs. Catena 50 (2), 91-133.

Price, S.P., Scott, B., 1991. Pliocene Burdur basin, SW Turkey: tectonics, seismicity and sedimentation. J. Geol. Soc. 148 (2), 345-354

Renard, K.G., Foster, G.R., Weesies, G., McCool, D., Yoder, D., 1997. Predicting Soil Erosion by Water: A Guide to Conservation Planning with the Revised Universal Soil Loss Equation (RUSLE), 703. US Government Printing Office Washington, DC.

Renssen, H., Seppä, H., Heiri, O., Roche, D., Goosse, H., Fichefet, T., 2009. The spatial and temporal complexity of the Holocene thermal maximum. Nat. Geosci. 2 (6), 411-414.

Rommens, T., Verstraeten, G., Poesen, J., Govers, G., van Rompaey, A., Peeters, I., Lang, A., 2005. Soil erosion and sediment deposition in the Belgian loess belt during the Holocene: establishing a sediment budget for a small agricultural catchment. The Holocene 15 (7), 1032-1043.

Rommens, T., Verstraeten, G., Bogman, P., Peeters, I., Poesen, J., Govers, G., van Rompaey, A. Lang, A., 2006. Holocene alluvial sediment storage in a small river catchment in the loess area of central Belgium. Geomorphology 77 (1-2), 187-201. 
Rommens, T., Verstraeten, G., Peeters, I., Poesen, J., Govers, G., Van Rompaey, A., Mauz, B. Packman, S., Lang, A., 2007. Reconstruction of late-Holocene slope and dry valley sediment dynamics in a Belgian loess environment. The Holocene 17 (6), 777-788.

Royall, D., Kennedy, L., 2016. Historical erosion and sedimentation in two small watersheds of the southern Blue Ridge Mountains, North Carolina, USA. Catena 143, 174-186.

Schulte, L., 2002. Climatic and human influence on river systems and glacier fluctuations in southeast Spain since the Last Glacial Maximum. Quat. Int. 93, 85-100.

Schumm, S.A., 1977. The Fluvial System. Willey, New York.

Simon, A., Rinaldi, M., 2000. Channel instability in the loess area of the Midwestern United States. J. Am. Water Resour. Assoc. 36 (1), 133-150.

Sintubin, M., Muchez, P., Similox-Tohon, D., Verhaert, G., Paulissen, E., Waelkens, M., 2003. Seismic catastrophes at the ancient city of Sagalassos (SW Turkey) and their implications for seismotectonics in the Burdur-Isparta area. Geol. J. 38 (3-4), 359-374.

Six, S., 2004. Holocene Geomorphological Evolution Of The Territory of Sagalassos, Leuven. Department of Earth and Environmental Sciences, KU Leuven (PhD thesis).

Slaymaker, O., 2003. The sediment budget as conceptual framework and management tool. The Interactions between Sediments and Water. Springer, pp. 71-82.

Stankoviansky, M., 2003. Historical evolution of permanent gullies in the Myjava Hill Land, Slovakia. Catena 51 (3), 223-239.

Steegen, A., Govers, G., Nachtergaele, J., Takken, I., Beuselinck, L., Poesen, J., 2000. Sediment export by water from an agricultural catchment in the Loam Belt of central Belgium. Geomorphology 33 (1), 25-36.

Stinchcomb, G., Messner, T., Driese, S., Nordt, L., Stewart, R., 2011. Pre-colonial (AD 1100$1600)$ sedimentation related to prehistoric maize agriculture and climate change in eastern North America. Geology 39 (4), 363-366.

Sutter, P.S., 2010. What gullies mean: Georgia's" Little Grand Canyon" and southern environmental history. J. South. Hist. 76 (3), 579-616.

Sutter, P.S., 2015. Let Us Now Praise Famous Gullies: Providence Canyon and the Soils of the South. University of Georgia Press.

Syvitski, J.P., Milliman, J.D., 2007. Geology, geography, and humans battle for dominance over the delivery of fluvial sediment to the coastal ocean. The Journal of Geology 115 (1), 1-19.

Syvitski, J.P., Vörösmarty, C.J., Kettner, A.J., Green, P., 2005. Impact of humans on the flux of terrestrial sediment to the global coastal ocean. Science 308 (5720), 376-380.

Thorndycraft, V.R., Benito, G., 2006a. The Holocene fluvial chronology of Spain: evidence from a newly compiled radiocarbon database. Quat. Sci. Rev. 25 (3-4), 223-234.

Thorndycraft, V.R., Benito, G., 2006b. Late Holocene fluvial chronology of Spain: the role of climatic variability and human impact. Catena 66 (1-2), 34-41.

Trimble, S.W., 1974. Man-induced soil erosion on the southern Piedmont. Soil Conserv. Soc. Am., Ankeny, Iowa 1700-1970.

Trimble, S.W., 1975. Denudation studies: can we assume stream steady state? Science 188 (4194), 1207-1208.

Trimble, S.W., 1981. Changes in sediment storage in the Coon Creek basin, Driftless Area, Wisconsin, 1853 to 1975 . Science 214 (4517), 181-183.

Trimble, S.W., 1983. A sediment budget for Coon Creek basin in the Driftless Area, Wisconsin, 1853-1977. Am. J. Sci. 283 (5), 454-474.

Trimble, S.W., 1999. Decreased rates of alluvial sediment storage in the Coon Creek Basin, Wisconsin, 1975-93. Science 285 (5431), 1244-1246.

Trimble, S.W., 2008. The use of historical data and artifacts in geomorphology. Prog. Phys. Geogr. 32 (1), 3-29.

Trimble, S.W., 2009. Fluvial processes, morphology and sediment budgets in the Coon Creek Basin, WI, USA, 1975-1993. Geomorphology 108 (1), 8-23.

Trimble, S.W., 2010. Streams, valleys and floodplains in the sediment cascade. In: Burt, T. Allison, R. (Eds.), Sediment Cascades. An integrated approach. Willey-Blackwell, Chichester, United Kingdom, pp. 307-344.

Trimble, S.W., 2013. Historical Agriculture and Soil Erosion in the Upper Mississippi Valley Hill Country. CRC Press.

Trimble, S.W., Lund, S.W., 1982. Soil Conservation and the Reduction of Erosion and Sedimentation in the Coon Creek Basin, Wisconsin. 2330-7102.

Van Andel, T.H., Runnels, C.N., Pope, K.O., 1986. Five thousands years of land use and abuse in the Southern Argolid, Greece. Hesperia: The Journal of the American School of Classical Studies at Athens 55 (1), 103-128.

Van Loo, M., Dusar, B., Verstraeten, G., Renssen, H., Notebaert, B., D'Haen, K., Bakker, J. 2017. Human induced soil erosion and the implications on crop yield in a small mountainous Mediterranean catchment (SW-Turkey). Catena 149, 491-504.

van Oost, K., Govers, G., Cerdan, O., Thauré, D., van Rompaey, A., Steegen, A., Nachtergaele, J., Takken, I., Poesen, J., 2005. Spatially distributed data for erosion model calibration and validation: the Ganspoel and Kinderveld datasets. Catena 61 (2), 105-121.
Van Oost, K., Verstraeten, G., Doetterl, S., Notebaert, B., Wiaux, F., Broothaerts, N., Six, J. 2012. Legacy of human-induced $C$ erosion and burial on soil-atmosphere $C$ exchange. Proc. Natl. Acad. Sci. 109 (47), 19492-19497.

Vanacker, V., von Blanckenburg, F., Govers, G., Molina, A., Poesen, J., Deckers, J., Kubik, P., 2007. Restoring dense vegetation can slow mountain erosion to near natural benchmark levels. Geology 35 (4), 303-306.

Vandenberghe, J., 1995. Timescales, climate and river development. Quat. Sci. Rev. 14 (6), 631-638.

Vandenberghe, J., 2008. The fluvial cycle at cold-warm-cold transitions in lowland regions: a refinement of theory. Geomorphology 98 (3), 275-284.

Vanmaercke, M., Poesen, J., Govers, G., Verstraeten, G., 2015. Quantifying human impacts on catchment sediment yield: a continental approach. Glob. Planet. Chang. 130 $22-36$.

Vanmontfort, B., 2007. Bridging the gap. The Mesolithic-Neolithic transition in a frontier zone. Documenta Praehistorica 34, 105-118.

Vanwalleghem, T., van den Eeckhaut, M., Poesen, J., Deckers, J., Nachtergaele, J., van Oost, K., Slenters, C., 2003. Characteristics and controlling factors of old gullies under forest in a temperate humid climate: a case study from the Meerdaal Forest (Central Belgium). Geomorphology 56 (1), 15-29.

Vanwalleghem, T., Bork, H., Poesen, J., Schmidtchen, G., Dotterweich, M., Nachtergaele, J. Bork, H., Deckers, J., Brüsch, B., Bungeneers, J., 2005a. Rapid development and infilling of a buried gully under cropland, central Belgium. Catena 63 (2), 221-243.

Vanwalleghem, T., Poesen, J., van den Eeckhaut, M., Nachtergaele, J., Deckers, J., 2005b. Reconstructing rainfall and land-use conditions leading to the development of old gullies. The Holocene 15 (3), 378-386.

Vanwalleghem, T., Poesen, J., McBratney, A., Deckers, J., 2010. Spatial variability of soil horizon depth in natural loess-derived soils. Geoderma 157 (1), 37-45.

Vermoere, M., Bottema, S., Vanhecke, L., Waelkens, M., Paulissen, E., Smets, E., 2002. Palynological evidence for late-Holocene human occupation recorded in two wetlands in SW Turkey. The Holocene 12 (5), 569-584.

Verstraeten, G., 2012. Combining quantitative field and modelling approaches towards understanding landscape dynmics: an evolution of ideas spanning Jef Vandenberghe's research career. Netherlands Journal of Geosciences-Geologie En Mijnbouw 91 (1/2), 133-244.

Verstraeten, G., 2014. Quantification of human-environment interactions in the past Anthropocene 8, 1-5.

Verstraeten, G., Poesen, J., Demarée, G., Salles, C., 2006. Long-term (105 years) variability in rain erosivity as derived from 10-min rainfall depth data for Ukkel (Brussels, Belgium): implications for assessing soil erosion rates. J. Geophys. Res. Atmos. 111 (D22).

Verstraeten, G., Rommens, T., Peeters, I., Poesen, J., Govers, G., Lang, A., 2009. A temporarily changing Holocene sediment budget for a loess-covered catchment (central Belgium). Geomorphology 108 (1-2), 24-34.

Vita-Finzi, C., 1969. The Mediterranean Valleys: Geological Changes in Historical Times 165. Cambridge University Press Cambridge.

Waelkens, M., Paulissen, E., Vermoere, M., Degryse, P., Celis, D., Schroyen, K., de Cupere, B. Librecht, I., Nackaerts, K., Vanhaverbeke, H., 1999. Man and environment in the territory of Sagalassos, a classical city in SW Turkey. Quat. Sci. Rev. 18 (4), 697-709.

Walling, D.E., 1983. The sediment delivery problem. J. Hydrol. 65 (1-3), 209-237.

Walling, D., Fang, D., 2003. Recent trends in the suspended sediment loads of the world's rivers. Glob. Planet. Chang. 39 (1), 111-126.

Walter, R.C., Merritts, D.J., 2008. Natural streams and the legacy of water-powered Mills. Science 319 (5861), 299-304.

Wang, H., Yang, Z., Saito, Y., Liu, J.P., Sun, X., Wang, Y., 2007. Stepwise decreases of the Huanghe (Yellow River) sediment load (1950-2005): impacts of climate change and human activities. Glob. Planet. Chang. 57 (3), 331-354.

Widlok, T., Aufgebauer, A., Bradtmöller, M., Dikau, R., Hoffmann, T., Kretschmer, I. Panagiotopoulos, K., Pastoors, A., Peters, R., Schäbitz, F., 2012. Towards a theoretica framework for analyzing integrated socio-environmental systems. Quat. Int. 274 259-272.

Williams, M., 2003. Deforesting the Earth: From Prehistory to Global Crisis. University of Chicago Press.

Wittmann, H., von Blanckenburg, F., Maurice, L., Guyot, J.-L., Filizola, N., Kubik, P.W., 2010 Sediment production and delivery in the Amazon River basin quantified by in situ-produced cosmogenic nuclides and recent river loads. Geol. Soc. Am. Bull. B30317, 30311.

Zolitschka, B., Behre, K.-E., Schneider, J., 2003. Human and climatic impact on the environment as derived from colluvial, fluvial and lacustrine archives-examples from the Bronze Age to the Migration period, Germany. Quat. Sci. Rev. 22 (1), 81-100. 